\title{
ECONOMICS
}

\section{MEASURING HARD POWER: CHINA'S ECONOMIC GROWTH AND MILITARY CAPACITY}

\author{
by
}

Peter E. Robertson

Business School

University of Western Australia

and

Adrian Sin

Business School

University of Western Australia 


\title{
Measuring Hard Power: China's Economic Growth and Military Capacity
}

\author{
Peter E. Robertson * \\ The University of Western Australia \\ Adrian Sin \\ The University of Western Australia
}

22 September 2013

\section{DISCUSSION PAPER 13.32}

\begin{abstract}
China's rapid economic development has facilitated a dramatic increase in its military capacity and international security presence. But there is considerable disagreement over how large its economy and military capacity is. Underlying the debate is the fact that market and PPP exchange rate comparisons give very different pictures of China's relative economic size, and neither is the appropriate price deflator with which to compare relative military capacities. We address this issue by deriving a relative military cost (RMC) exchange rate for China which converts RMB to US dollar expenditures in terms of real military services. This shows that both market and PPP exchange rate comparisons of China's real GDP understate its relative military capacity. Nevertheless we also show that the real expansion of China's military capacity over the last decade has been much smaller than its GDP growth, due to the rapidly growing wage costs faced by China's military.
\end{abstract}

Keywords: China; Foreign Policy National Security; Index Numbers; International Comparisons.

JEL: P16; H56; O57; C43; F52

\footnotetext{
${ }^{*}$ Corresponding Author; P. Robertson, Economics, School of Business, University of Western Australia, Perth. Email: peter.robertson@uwa.edu.au. We are grateful to Robert Hill and seminar participants at U.W.A. for comments on this paper.
} 


\section{Executive Summary}

- China's economic growth has allowed a commensurate expansion in its military capacity and international security presence.

- Nevertheless, recent studies by The Rand Corporation and the U.S. Department of Defense, stress that we lack appropriate price indices needed to compare military capacities across countries.

- This paper describes a new method for making international comparisons of real potential military spending.

- We find that conventional exchange rate comparisons of China's real GDP, or military spending, understate China's military capacity compared to the USA.

- However we also show that the real expansion of China's military capacity over the last decade has been much smaller than its GDP growth.

- As an example we find that China's military spending relative to the USA has grown by only $32 \%$ over the last decade compared to the conventional estimate of $131 \%$ based on market exchange rates.

- The principle reasons for these results is the low cost of labor and China, and the rapid growth of wages which have driven up personnel costs. 


\section{Introduction}

China's rapid economic growth has lifted hundreds of millions of people from absolute poverty and dramatically raised the living standards of many more. ${ }^{1}$ But its growth has also caused a great deal of interest in its impact on the world economy, for example in terms of in terms of its relative GDP, and its world shares of trade, investment and savings (Deaton and Heston 2010, Subramanian 2011, The Economist 2011, Feenstra et al 2013).

Likewise there has been a growing awareness of the enormous implications for international relations and security. ${ }^{2}$ (Legro 2007, Fravel 2005, 2008a, 2008b, Layne 2009, Thompson 2010, Shambaugh 2013). Of interest is how China will use its economic and military strengths to resolve territorial disputes in the South and East China Seas, the North Korean problem and its claims over Taiwan (U.S. Department of Defense 2011, White 2012, Wortzel 2013). ${ }^{3}$ Even in the absence of any territorial disputes, China's greatly expanded military capacity enhances its political bargaining power and requires reassessment of national strategies security and diplomatic strategies (Dobbins 2011, White 2012).

Current assessments of China's military capacity, however, range from disquieting analyses, such as Kaplan $(2005,2010)$ and Mearsheimer (2006) to relatively restrained views, such as Thompson (2010), Etzioni (2011) and Shambaugh (2013). Underlying these different views is a fundamental uncertainty that results from the difficulty of making international comparisons of real GDP. Specifically, estimates of China's real GDP in terms of $\$$ US vary enormously depending on whether Purchasing Power Parity (PPP) or market exchange rates are used and the different methods for deflating nominal spending into real output or capacity (Feenstra et al 2013, Robertson 2013).

Consequently there is an acute interest in obtaining comparable measurements of China's economic size and the implications for its military capacity (Crane et al 2005, U.S. Department of Defense 2011). In particular numerous studies, for example by The Rand

\footnotetext{
${ }^{1}$ Chen and Ravallion (2010) report that the number of people in China living below the $\$ 1.25$ per day poverty line fell by 600 million since 1980 .

${ }^{2}$ Johnston (2013) finds a seven fold increase in newspaper, other media and academic articles on "Chinese assertiveness" since 2008. For examples of the popular discussion and issues see The Economist specifically: 2 December 2010; 9 June 2012 and; April 7, 2012.

${ }^{3}$ According to the US Department of Defense (2011), China has land boundary disputes with India and maritime disputes with Japan as well as disputes over the South China Sea (Vietnam, Malaysia, the Philippines, Brunei, Taiwan). China argues that the development of maritime capabilities is intended to build capacity for international peacekeeping, humanitarian assistance, disaster relief, and protection of sea lanes.
} 
Corporation, The Brookings Institution and the U.S. Department of Defense, have expressed dissatisfaction with both PPP and market exchange rate comparisons for the purpose of evaluating real military capacity across countries (Crane et al 2005, O'Hanlon 2009, U.S. Department of Defense 2007, 2011).

The most appropriate way to compare real military capacity across countries is to deflate each country's actual, or potential, military spending by the price of real military services in each country. Unfortunately military price indices do not exist for most countries. The aim of this paper, therefore, is to develop a simple method for computing a relative military price index, that deflates nominal spending into units of real military services, using readily accessible data. The ratio of two countries' military price indices then gives an exchange rate that provides an index of relative real military capacity across countries. We use this military exchange rate to compare the level and growth of China's real military capacity relative to the USA. ${ }^{4}$

We obtain two key results. First we find that the value of the RMB, in terms of its ability to purchase real military services, is greater than both its market exchange rate value and its PPP value. This suggests that conventional estimates of GDP understate China's real military capacity, but also that PPP exchange rate comparisons are much closer to the actual value than market exchange rate comparisons. This is mainly because of the very low cost of labor in China relative to the USA.

Second we find that the expansion of China's military capacity over the last decade is much lower than standard measures of military spending growth relative to the USA. The reason for this is that personnel costs have risen dramatically due to rising wages in China since 2000. This raises military unit costs relative to aggregate economy-wide price indices that are currently used in the economic literature and in defence statistical abstracts, thus leading to lower real expansion in military capacity.

\section{The Measurement of Real Military Capacity}

Tellis et al (2000) define "national power" as the capacity of a country to pursue strategic goals through purposeful action. This makes a clear link between international politics and the economy (Morgenthau 1948, Mearsheimer 2001). Specifically, the credibility of any territorial claims or demands upon foreign nations depends on a country's economic

\footnotetext{
${ }^{4}$ In contrast to the literature on military spending, the focus is not on the accuracy of military spending data, or on its effects, but on the appropriate way to compare spending levels across countries.
} 
capacity to sustain military operations. ${ }^{5}$

Though military capacity depends on current military spending levels, ultimately a country's ability to sustain spending on military services depends on its economic wealth. For example, according to Smith (2009), US and UK spending levels exceeded $40 \%$ of GDP during WWII. But, as also noted by Smith (2009) and Shambaugh (2013), the Soviet Union's defence spending budget in the 1970s of $20 \%$ of GDP was regarded as being unsustainable and ultimately contributed to the Soviet Union's collapse. Across all countries, military budgets in 2012 averaged $1.9 \%$ of GDP and only 4 countries had a military budget that exceeded $5 \%$ of GDP (SIPRI 2012).

Hence a country's military capacity is constrained by its economic resources and the ability to expand a country's military capacity over the longer term depends mainly on its economic growth. Relative GDP is therefore an appropriate and parsimonious starting point for thinking about countries' relative military capacities. This essentially allows us to compare countries as if they spent a similar proportion of their income of defense. ${ }^{6}$ For completeness, however, we consider comparisons of both real current military spending levels across China and the USA, as well as real GDP. In either case the key question is how to compare these spending levels in different currencies in terms of what they imply for each country's relative real military capacity.

\subsection{International Comparisons of Real Military Capacity}

In order to measure how different values of GDP across countries result in different potential military capacities, we need an exchange rate to convert units of spending in local currency into a common currency. Standard international comparisons of real output across countries are based on either market exchange rates or PPP exchange rates, such as those produced by the ICP project of the World Bank. The well documented problem with using market exchange rates for this purpose is that many goods and services have different relative prices within a country, with non-traded goods being relatively less expensive in poorer countries. This means, for example, that a dollar, converted to RMB at market exchange rates and spent in China, can typically purchase more goods and services than the same dollar spent in the USA. The PPP exchange rate

\footnotetext{
${ }^{5}$ There is a debate in the literature on what other factors should be considered for determining a country's political influence. With respect to China's rise see Subramanian (2011), Beckley (2012), Shifrinson et al (2012) and Shambaugh (2013).

${ }^{6}$ Data on military spending is notoriously of poor quality and China's official data are widely regarded to be understated (Brzoska 1995, Ball 1984, Department of Defense 2005, ISSS 2006, O'Hanlon 2009, Smith 2009).
} 
thus aims to measure the cost of a given bundle of goods in different countries so as to compare living standards across countries. ${ }^{7}$

If we wish to infer country's miliary capacity based on the size of its economy, however, standard PPP indices also pose a problem insofar as they reflect the relative price of an average basket of goods produced in the economy and this average price index may differ substantially from the price of military services. Thus Crane et al (2005) argue that, while military services have large personnel costs, a substantial share of military equipment purchased by developing-country militaries is imported or incorporates components that are manufactured from materials and parts sold at world market prices, such as electronics, diesel engines, or aircraft frames. Thus they suggest that, for some purposes, GDP measured at market exchange rates may give a more realistic picture of changes in military capacity (Crane et al 2005, pp.16-17).

Similarly, the two principle military statistical abstracts, The Military Balance published by The International Institute for Strategic Studies (IISS), and the Stockholm International Peace Research Institute's (SIPRI) Yearbook report relative military spending and relative GDP in terms of $\$$ US converted at market exchange rates and also at PPP exchange rates. IISS (2012) notes that market exchange rates are likely to understate the true level of economic resources allocated towards defence since food material and housing costs will be lower in China, but remain noncommittal in recommending a preferred price index. $^{8}$ Thus they often report a weighted average of PPP and market exchange rates when discussing China's real military capacity relative to the USA.

The extent of the differences between these measures can be seen in Figure 1 which shows the ratio of Chinese to USA GDP evaluated at both market exchange rates and at PPP exchange rates taken from the Penn World Table (Heston et al 2012). The Penn World Table has two PPP measures which reflect alternative measures of China's growth. "PPP China Version 1" reflects official data while "PPP China Version 2" is an adjusted series

\footnotetext{
${ }^{7}$ There are different types of PPP exchange rates. See for example Hill and Hill (2009) and Diewert (2010) for general discussions and Deaton and Heston (2010), Feenstra et al (2013) with respect to China.

${ }^{8}$ They note that "no specific PPP rate exists for the military sector" and urge caution when interpreting their economic data since "there is no definitive guide as to which elements of military spending should be calculated using the PPP rates available" (IISS 2012, pp.215-216). This issue has received very little attention in the economics literature despite being discussed widely at a superficial level in the international security literature. The United Nations (1986) used relatively detailed price data to calculate military PPP indices for eight countries and Heston and Aten (1993) estimated real military expenditures across countries for 1985, using cross country regressions to extrapolate data from ICP benchmark countries. Crane et al (2005) look explicitly at the issue of China's growth and attempts to adjust China's PPP to take account of traded and non-traded goods in a way that reflects military shares.
} 
based on the work of Maddison and Wu (2008). ${ }^{9}$ It can be seen that, using PPP exchange rates, China's GDP is approximately $80 \%$ of the USA, whereas using market exchange rates it is approximately $40 \%$ of USA GDP.

We can similarly compare the shares of each country's GDP dedicated to military spending. Though China's GDP has grown much faster than the USA, as shown in Figure 2, its share of spending on military has declined - particularly through the early 1980s when its economy was growing rapidly. By comparison USA spending also declined during the 1980s but increased again after 2000. Figure 3 therefore shows the relative levels of military spending in \$US, using PPP and market exchange rates. Again it can be seen that the different measures of relative GDP imply very different levels of relative military spending in China, from $17 \%$ to $35 \%$ of USA level.

\subsection{Relative Growth in Military Capacity}

Alternatively, rather than attempting to compare the level of military capacity, we could restrict attention to the growth in real military capacity or spending relative to a base year. This requires only a rice index, as opposed to knowing the actual price level. Figure 4 thus shows the ratio of Chinese to USA real military spending indexed to 1 in 2000 using three different measures. The first index is simply the ratio of Chinese to USA real GDP in local currency units. The second two indices are the same data as presented in Figure 3, the relative GDP measured in US dollars converted at market and PPP exchange rates.

Again, however, it can be seen that there is a large difference in the three estimates of China's relative military capacity. The local currency and PPP measures suggest an expansion of $65 \%$ to $80 \%$. These differ substantially for the expansion measured in US dollars at market exchange rates which indicate a 2.3-fold (or 130\%) increase in China's real military capacity, caused by the appreciation of the RMB against the dollar.

These large differences - for example from a $65 \%$ to a $130 \%$ increase - arise from the different price deflators associated with each measure of real GDP growth and the significant difference in the growth of China's military expenditure when evaluated in US dollar terms or local currency units. Thus we have seen that standard price indices and exchange rates imply quite different measures of both the level and growth of China's military capacity.

\footnotetext{
${ }^{9}$ The results presented below, which focus on the period 2000-2010, are not affected in any significant way by this choice.
} 


\section{A Relative Military Cost Exchange Rate}

It is difficult to deflate nominal military spending into a real quantity since the output price of military services is not observed. Nevertheless, in principle, we can compare input prices and construct an appropriate input price index. As discussed by Crane et al (2005), the inputs used in producing defence services include a mix of traded and non-traded goods as well as personnel services. For example, inputs range from clothing, paper and electronics to aircraft frames, missiles and ships. Likewise personnel services include soldiers, cooks, and administrators. Thus we can proceed by using price data for these inputs, or aggregates prices for different types of inputs. Comparing the resulting total input price across countries would then give an exchange rate that converts units of nominal spending in one country into those of a reference country, such as US dollars.

To consider this we begin with the standard military budget conventions which divide military spending into Military Personnel, Operations and Maintenance, and Procurement of Equipment (Brzoska 1995). In the USA these three categories currently account for around $80 \%$ of the total budget. ${ }^{10}$

To develop a military price index based on this budget information, consider the economic decision of a defence sector that allocates its budget across the three broad expenditure types to provide military services, $M_{i}$. The sector takes prices as given and chooses an optimal input bundle to minimize costs taking prices and the total budget as given. We assume that the technology for combining Personnel, $n_{i}$, Operations $x_{i}$ and Equipment, $z_{i}$, is given by the function $f\left(n_{i}, x_{i}, z_{i}\right)$ which exhibits constant returns to scale and diminishing returns to each input. The cost minimization problem is

$$
\min C_{i}=p_{n, i} n_{i}+p_{x, i} x_{i}+p_{z, i} z_{i} \mid M_{i} \leq f\left(n_{i}, x_{i}, z_{i}\right)
$$

where $p_{n, i}$ is the input price for an effective (constant quality) unit of Personnel services, $n_{i}$, or the wage rate per effective unit of labor, $p_{x, i}$ is the price per effective unit of operations, $x_{i}$ and $p_{z, i}$ is the price per effective unit of equipment $z_{i}$. The minimum cost function is then

$$
C_{i}=c_{i}\left(p_{n, i}, p_{x, i}, p_{z, i}\right) M_{i}
$$

The cost function is linear in output, $M_{i}$, which follows from the assumption of constant returns to scale. Hence the unit cost function $c_{i}\left(p_{n, i}, p_{x, i}, p_{z, i}\right) \equiv c\left(p_{i}\right)$ is independent of scale.

\footnotetext{
${ }^{10}$ The remaining items are research, development and testing and military construction (O'Hanlon 2009).
} 
The aim is to compare real output indices, $M_{i}=C_{i} / c_{i}\left(p_{i}\right)$, across countries. Thus suppose we consider a country, $i$, to a reference country $k$. Then letting $m_{i, k} \equiv M_{i} / M_{k}$ be the true quantity index of country $i$ 's output relative to country $k$, from (2) we have

$$
m_{i, k}=\left(C_{i} / C_{k}\right) / e_{i, k}
$$

where

$$
e_{i, k} \equiv \frac{c_{i}\left(p_{i}\right)}{c_{k}\left(p_{k}\right)}
$$

is a true relative cost index, which we can interpret as a true price index. ${ }^{11}$ It is also an exchange rate since it is equal to the ratio of the cost of purchasing one unit of $M$ in $i$ relative to $k$. Thus $e_{i, k}$ is a true relative military cost (RMC) exchange rate that tells us what it would cost to purchase country $i$ 's defence bundle at the reference country prices, $k$, and hence would be the appropriate rate for comparing military spending across countries.

It may be useful to think of some extreme examples. First suppose defence spending consisted only of purchased goods, such as an automated missile defence shield system, with no personnel and that is imported. Then $e_{i, k}$ would simply be the ratio of prices of the goods in each country measured in local currency units, i.e. a pure monetary exchange rate. Alternatively suppose defence expenditure consisted only of labor (soldiers) and all labor was of equivalent skills. Then $e_{i, k}$ would be an index of relative wage rates measured in local currency units and equation (3) would simply be expenditure in each country divided by this relative wage ratio. Hence $m_{i, k}$ would simply be the ratio of the number of soldiers in each country.

More generally, (3) will describe the quantity of a bundle of military services comprising of Personnel, Operations and Equipment and (4) will be a function that expresses the number of units of one currency required to purchase the same bundle of services in units of the other country's currency, where the ratio depends on wage and military prices in each country. ${ }^{12}$ Thus when comparing military spending or GDP across countries using RMC exchange rate, the resulting ratio is, conceptually, a comparison of the bundle of defence or military capabilities, where the bundle in each region may differ but reflects the optimal bundle given the relative prices in each country.

\footnotetext{
${ }^{11}$ It is also referred to as a Konüs, price index.

${ }^{12}$ Naturally more factor inputs can be included if there is sufficient data.
} 


\section{Implementation}

One way to operationalize (3) would be to simply assume a particular form of the cost function. For illustrative purposes suppose that (3) is an iso-elastic function given by

$$
C_{i}=A_{i} p_{n, i}^{\theta} p_{x, i}^{\gamma} p_{z, i}^{1-\theta-\gamma} M_{i}
$$

where $A_{i}$ is the inverse efficiency index that captures quality changes in inputs or improvements in efficiency. By Shephard's Lemma, $\theta=d C_{i} / d p_{n, i}\left(p_{n, i} / C_{i}\right)=n p_{n, i} / C_{i}$ is the budget share of personnel in total costs and likewise $\gamma=x p_{x, i} / C_{i}$ and $1-\theta-\gamma=z p_{z, i} / C_{i}$.

Letting $a \equiv A_{k} / A_{i}$ then from (3) we have

$$
e_{i, k} \equiv a\left(p_{n, i} / p_{n, k}\right)^{\theta}\left(p_{x, i} / p_{x, k}\right)^{\gamma}\left(p_{z, i} / p_{z, k}\right)^{1-\theta-\gamma}
$$

Equation (6) is a Divisia index of three sets of relative prices each weighted by the relevant share of costs in the military budget.

To quantify (6) we would require data on the Personnel, Operations and Equipment shares of military spending and the various nominal price ratios measured in units of local currency. We can simplify the problem by appealing to the fact that a large amount of military equipment is tradable, or is produced using components that are tradable (Crane et al 2005). Hence arbitrage, or the law-of-one price, implies that the ratio of equipment prices is given by

$$
p_{z, i}=r_{i, k} p_{z, k}
$$

where $r_{i, k}$ is the bilateral monetary exchange rate between country $i$ and $k$, in units of $k$ 's currency per unit of $i$ 's currency.

Next we consider Operations, which is the part of the defence budget that largely consists of transport, storage, services and other inputs such as fuels. This includes a mix of traded and non traded goods. To determine the relative cost of operations, $p_{x, i} / p_{x, k}$, we simply use the PPP rate. $^{13}$

The remaining terms are the relative prices of personnel $\left(p_{n, i} / p_{n, k}\right)$ and the relative efficiency term $a$. To consider these first note that in (3) and (4) and the following expressions, there is an implicit assumption that all inputs are the same quality. Hence the relative price of personnel should reflect the relative prices of identical workers. Never-

\footnotetext{
${ }^{13}$ For comparing changes over time we could also use the GDP deflator, though this gives very similar results since the change in the PPP exchange rate is very similar to the change in the official GDP deflator.
} 
theless across two countries such as China and the USA there are likely to be significant differences in labor quality due to differences in human capital. ${ }^{14}$

To allow for this we require both a measure of actual personnel costs and also the average skill level or human capital embodied in that personnel. We therefore begin by obtaining actual wage data $\hat{p}_{n, i}$, which reflects the opportunity cost of military personnel. ${ }^{15}$ Then, given a human capital level or effective labor index in country $i$ of $h_{i}$, we can derive the wage per effective unit of labor as $p_{n, i}=\hat{p}_{n, i} / h_{i}$. In this way we can construct a nominal wage ratio per effective unit of labor of $w_{i, k} \equiv p_{n, i} / p_{n, k}=\left(\hat{p}_{n, i} / \hat{p}_{n, k}\right)\left(h_{k} / h_{i}\right)$.

Adjusting for differences in labor quality therefore captures an important difference in productivity across countries. In principle any additional productivity differences should be captured by the term $a$. This would mostly reflect governance and institutional structures within the military sector. In what follows we simply assume that the efficiency level of military services in each country is similar across countries, so that $a=1$. Hence after the appropriate adjustment for differences in labor quality described above, we assume there are no other significant differences in the efficiency of the organization itself. Moreover, for comparing the growth in military capacity, we only require the weaker assumption that $a$ is constant over time. ${ }^{16}$

With these considerations (6) becomes

$$
e_{i, k}=w_{i, k}^{\theta}\left(p_{x, i} / p_{x, k}\right)^{\gamma} r_{i, k}^{1-\theta-\gamma}
$$

\subsection{Index Numbers}

The Konüs price index derived in (6) and (8) is a Divisia index of relative prices in each country and assumes common budget shares across countries. However it makes assumptions about the functional form of the cost function which is unknown in prac-

\footnotetext{
${ }^{14}$ It may be tempting to think of this quality difference as also reflecting the additional equipment that a US soldier might have, however this is actually reflected in the expenditure and price indices of equipment not personnel. More generally, many of the differences that we associate with "technology" in colloquial language usage, should not be confused with differences in productivity. For example the higher "technological sophistication" of US military equipment is implicitly captured in (5) through its expenditure on equipment relative to personnel.

${ }^{15}$ This is important since even if military personnel are subsidized or conscripted, the burden on the economy, and hence its capacity to sustain military spending, is determined by the forgone productive capacity.

${ }^{16} \mathrm{An}$ additional concern might be that the quality of intermediate inputs is not measured properly. This is known to be a problem with the measurement of sectoral TFP growth in sectors using IT (Baily and Gordon 1988, Jorgenson and Stiroh 1999). In our case however we are only concerned with relative input quality change across countries, which will reduce any bias from input quality change.
} 
tice. Moreover the assumption that the input shares are the same across countries is contradicted by the evidence. This can be seen from Table 1, which shows Chinese and USA military budget shares for Personnel, Operations and Equipment taken from China Defense White Papers and USA government accounts. ${ }^{17}$

It can be seen that the shares are quite stable and also relatively similar across countries and time. China's personnel share has been consistently around 35\% and the USA's personnel share has fallen only slightly since 1980 from $30 \%$ to $25 \%$. China's share has also been relatively stable over this period. Nevertheless, although these shares are similar in China and the USA they are clearly not identical as assumed in (6).

Index number theory suggests several ways to deal with both these problems of unknown cost functions and different factor shares. First we may use a Törnqvist price index, which is defined as

$$
e_{i, k}^{T}=a w_{i, k}^{\left(\theta_{i}+\theta_{j}\right) / 2}\left(p_{i} / p_{k}\right)^{\left(\gamma_{i}+\gamma_{j}\right) / 2} r_{i, k}^{\left(1-\theta_{i}-\gamma_{i}+1-\theta_{i}-\gamma_{j}\right) / 2}
$$

and the Törnqvist quantity index is $m_{i, k}^{T}=\left(C_{i} / C_{k}\right) / e_{i, k}^{T}$. It can be seen that this index is very similar to (8) but uses the average of each country's budget shares.

An alterative widely used index is the the Fisher "ideal" index, which is a geometric average of the Laspeyres and Paasche indices. Specifically suppose we define the value of $i$ 's purchases of military inputs, evaluated at $k$ 's prices, as a Laspeyres quantity index, $m_{i, k}^{L}$. Likewise $k$ 's outputs valued at $i$ 's prices is then a Paasche quantity index of relative military outputs $m_{i, k}^{P}$. If $e_{i, k}^{P}$ and $e_{i, k}^{L}$ are the associated Paasche and Laspeyres price indices, the Fisher ideal index of the exchange rate is

$$
e_{i, k}^{F}=a\left(e_{i, k}^{P} e_{i, k}^{L}\right)^{\frac{1}{2}}
$$

and the Fisher quantity index is $m_{i, k}^{F}=\left(C_{i} / C_{k}\right) / e_{i, k}^{F}$.

Thus we can compare the relative growth of real military capacity in each country by deflating the ratio of nominal spending in two countries, $i$ relative to $k$, in local currency units, using either of the exchange rate indices (9) or (10). Both are different approximations to the relative costs of military spending in each country. In particular both the

\footnotetext{
${ }^{17}$ Data for the USA is taken from http://www.whitehouse.gov/omb/budget/Historicals/ from Table 5.1. "Personal" and "Equipment" shares are calculated from the Military Personnel and Procurement headings respectively, and total expenditure is calculated from row 051, Subtotal, Department of DefenseMilitary. "Operations" is the residual category. For China, the data are taken from various issues of China Defence White Papers, China's National Defense in 2000, 2002, 2004, 2006, 2008, 2010, published by Peoples' Republic of China, and available from http://merln.ndu.edu/whitepapers.html.
} 
Törnqvist and Fisher indices are "superlative", meaning that they are exact cost indices for particular functional forms of the cost function. The Törnqvist is exact for a translog production function and is equivalent to the Konüs or Divisia index in (8) if the factor shares are constant. The Fisher is exact for a quadratic function and, in the absence of technological change, is nested between the Laspeyres and Paasche indices. Moreover both of these may also be regarded as second order approximations to some true cost function (Diewert 1978, Allen and Diewert 1981, Hill 2006). ${ }^{18}$

\subsection{Data on Relative costs}

Aside from the budget shares the necessary data consist of the relative wage per unit of effective labor, the index of domestic prices and the exchange rate.

To compute relative wages per unit of equivalent labor we take average wages in manufacturing from the USA and China and divide this by an index of human capital attainment in each country. We follow previous studies such as Klenow and Rodriguez-Clare (1997) and Bosworth and Collins (2008) who adopt the Mincerian relationship between the effective units of labor (human capital index) $h$, and years of schooling, $s$, given by $h=e^{\phi s}$, where $\phi$ is estimated to be approximately 0.15 , based on Mincerian returns-to-schooling literature. The years of schooling, $s$, is taken from Barro and Lee (2010). By this measure a Chinese manufacturing worker was equivalent in skills to 0.43 of a USA worker in 2000, and this rises to 0.47 by 2010. As discussed above this human capital adjustment is important since better educated labor will reduce military training costs. Moreover there has been relatively rapid growth in the average years of schooling in China, so that this is a potential source of real military expansion for China.

The relative price data are shown in Figure 5 and Table 2. The main feature of the data is the steep rise in the wage per effective worker in China relative to the USA. These rising wage costs are key to the results presented below and are readily understood as a result of general equilibrium adjustments in the Chinese economy.

This type of price effect reflects a general equilibrium effect sometimes referred to as "Baumol's-cost" disease. ${ }^{19}$ The growth of wages represents rising labor productivity in

\footnotetext{
${ }^{18}$ Hill (2006) shows that quadratic-mean-of-order- $r$ superlative indices with high values of $r$, are sensitive to extreme values and may give very different values. The Fisher index is the mean-of-order-2 $(r=2)$ superlative index and the Törnqvist is the $r=0$ superlative index. Though there are an infinite number of superlative indices the Fisher and Törnqvist are the most widely used and Hill (2006) shows that the Fisher and Törnqvist indices have additional axiomatic properties that make them preferable.

${ }^{19}$ It is also very similar to the "Dutch Disease" (Corden and Neary 1982). For the market sector these relative price effects cause an economic restructuring with some sectors expanding and others
} 
the manufacturing sector which results in rising wages across the whole economy. ${ }^{20}$ In particular, a unified wage adjustment policy for all personnel of Chinese government and State enterprises has resulted in rising wages faced by the military sector along with increases in social security and medical benefits (Peoples' Republic of China 2004, IISS 2006).

Looking at the other price indices in Figure 5 it can be seen that Chinese prices, as measured by the PPP index, have risen slightly relative to the USA since 2000 and the RMB has appreciated relative to the dollar - which indicated by a fall in the relative price level in Figure 5 reflecting the lower cost of foreign imports. Like rising wage costs these changes also reflect general equilibrium effects of China's growth. The boom in the tradable goods sector, through rising productivity or falling trade costs or deregulation as a result of WTO accession, causes not only rising wages but also a real exchange rate appreciation, by increasing domestic prices. Thus the growth in China's manufacturing productivity has costs and benefits for the defence sector. The costs may be mitigated to the extent that the defence sector can substitute personnel for imported technology which has become cheaper due to the appreciation of the RMB.

Finally the pattern between the nominal and real exchange rates also reflects the BalasaSamuelson effect which says that the gap between the nominal exchange rate level and the PPP exchange rate level will close over time as prices in China converge on USA relative prices. The appreciating nominal exchange rate and rising Chinese price level relative to the USA represents a convergence of these two rates since the level of the nominal exchange rate is historically above the PPP exchange rate.

Thus the pattern in these price trends reflects the general equilibrium adjustments of China's rapid growth. Nevertheless, as we shall see, the implications for the Defence sector are profound and the impact of these rising personnel costs has not been subjected to any analytical critique in the economics literature.

contracting through Rybczyinski effects. If the government fixes the military budget, then faced with rising personnel costs it may also contract. Alternatively however the government could potentially increase spending to maintain a similar supply of real military services.

${ }^{20}$ The wage data here are manufacturing wages and it might be argued that military salaries may not have risen as fast as manufacturing wages. However, even if military salaries had not risen, manufacturing wages represent the opportunity cost of military personnel and hence also the relevant social cost on the economy. 


\section{Results}

\subsection{Relative Military Cost $(R M C)$ Price Indices}

We may now consider the implied RMC exchange rates $e_{i, k}^{T}$ and $e_{i, k}^{F}$, which are computed from the exchange rate and wage data. The results are given in Table 3 and summarized in Figures 6 and 7. Figure 6 also reports the values of the RMC Törnqvist Fisher exchange rates , $e_{i, k}^{T}$ and $e_{i, k}^{F}$ along with the market and PPP exchange rates for reference. Figure 7 reports the same data indexed to 1 in 2000 in order to compare the growth rate of each exchange rate.

In terms of levels, it can immediately be seen from Figure 6 that both the RMC exchange rates are smaller than the PPP exchange rate. The results thus challenge the received wisdom that an exchange rate based on relative military costs would lie in between the PPP and markets exchange rates. Intuitively this says that, compared to an average basket of all produced goods, military goods are relatively inexpensive in China compared to the USA. As discussed above this reflects the fact that wages in China are very low, even after we make quality adjustments allowing for differences in human capital.

As we have seen, China's relative wage ratio grew quickly since 2000, which means that the RMC exchange rates, $e_{i, k}^{T}$ and $e_{i, k}^{F}$ also grow more quickly than the market and PPP exchange rates, as shown in Figure 7 . It can be seen that using the PPP rate as an index of military costs would imply that costs relative to the USA have increased by $10 \%$. Using the market exchange rate implies that costs in China have fallen $20 \%$, due to the appreciation of the RMB. But Figure 6 shows that the RMC exchange rates both rise considerably more, with $e_{i, k}^{T}$ increasing by $30 \%$ since 2000 and $e_{i, k}^{F}$ increasing by $50 \%$ since 2000 .

Thus the RMC exchange rates are low because wages per efficiency unit are low in China and the military has a relatively large personnel share. Moreover because of the sharp increase in relative wages, the RMC exchange rates show Chinese-to-USA military costs rising much faster than the conventional exchange rates that are used in the literature.

\section{Real Military Output}

The preceding results suggest that conventional exchange rates understate the increase in these relative costs that are facing the Chinese military. The implications for comparisons 
of real military output are given in Table 3 which reports the value of $m_{i, k}^{F}=\left(C_{i} / C_{k}\right) / e_{i, k}^{F}$ and $m_{i, k}=\left(C_{i} / C_{k}\right) / e_{k, i}^{T}$ where $C_{i}$ and $C_{k}$ are the shares of military spending multiplied by nominal GDP in local currency, from the Penn World Table. The results are summarized in Panels (i) and (ii) of Figure 8 which show both the levels and growth of real military spending in China relative to the USA. It can be seen from panel (i) that if Chinese military spending is converted to \$US using our RMC index, the Chinese level is about $27-32 \%$ of the USA level in 2000 using the Törnqvist and Fisher indices, and increased respectively to $39 \%$ and $42 \%$ by 2010 . These values are a little larger in magnitude to the relative size obtained using PPP exchange rates (20-33\%) and much larger than the level obtained using market exchange rates (8-18\%).

Thus, though the existing literature conjectures that a RMC exchange rate would lie between the PPP and market exchange rates, our results suggest that both the PPP and market exchange rates understate the actual relative military capacity. The larger value reflects the very low cost of labor in China and the relative labor intensity of defence services. Taking into account the uncertainty in this measure arising from standard data quality issues as well as the assumption regarding equivalent efficiency levels in each region, the results should be treated with an appropriate degree of caution. ${ }^{21}$ Nevertheless they strongly suggest that the true relative military capacity of China relative to the USA is a ratio that is much closer to standard PPP comparisons of military spending than market exchange rate comparisons.

This is important since it takes into account both composition of the military including its high labor share as well as the issue raise by Crane et al (2005) that much equipment can be imported. The results show, however, that the low wage costs tend to dominate. Specifically, given the low wage cost (per efficiency unit) in China, it makes economic sense for China to adopt a labor intensive method of producing military services.

Arguably of greater interest is how much China's actual capacity has expanded over recent years, since this goes to the core issue of how much the military and political balance has changed recently. As was shown in Figure 4, estimates of China's real military expansion relative to the USA range widely from $65 \%$ to $135 \%$. Panel (ii) of Figure 8 reports the growth of China's real military spending relative to the USA using the RMC exchange rate. Compared to the conventional view of $65 \%$ to $135 \%$, the increase is only $43 \%$ using the Törnqvist cost function index, and $32 \%$ using the Fisher index. Thus the growth in China's military output relative to the USA, using RMC price indices, is much smaller than the conventional measures.

\footnotetext{
${ }^{21}$ Hence the relative levels, $m_{i, k}=\left(C_{i} / C_{k}\right) / e_{k, i}^{T}$ in Figure 8 should be viewed as an upper limit on the size of China's real military capacity, relative to the USA.
} 
This smaller real expansion is due to the rapid increase in the RMC exchange rate shown in Figure 7, which, as discussed above, is due to the increase in wage costs in China after 2000. In essence, China's military, in the face of rising wages, has had to spend more to maintain the same level of personnel salaries. With personnel costs occupying $20-30 \%$ of the total budget this reflects a large increase in overall military or defence sector costs. Again this is important since it shows that, despite the rapidly appreciating exchange rate in recent years, China's military costs have escalated with the benefits of the rising exchange rate being dominated by the higher personnel costs.

\section{$7 \quad$ Real Potential Military Capacity}

The preceding results refer only to military spending. As discussed above focusing only on actual spending understates the shifts in the relative potential capacity of each country. In particular, China spends a much smaller fraction of its GDP on the military than the USA currently does and this could easily be expanded. Moreover there is considerable uncertainty over the actual versus official size of military budgets (O'Hanlon 2009, Smith 2009). Hence, as discussed above, rather than focusing just on actual current military spending, we also consider potential spending since this also important in terms of determining a country's influence in international political affairs.

To evaluate relative potential capacity, panels (iii) and (iv) of Figure 8 report the relative GDP of China and the USA evaluated using the RMC exchange rates. This effectively gives the relative military capacity of each country assuming that both countries spend the same fraction of GDP on military services. Thus we evaluate Törnqvist and Fisher indices of relative GDP in terms of real military output, denoted respectively $y_{i, k}^{T}$ and $y_{i, k}^{F}$, where $y_{i, k}^{T} \equiv\left(Y_{i} / Y_{k}\right) / e_{i, k}^{T}$ and $y_{i, k}^{F} \equiv\left(Y_{i} / Y_{k}\right) / e_{i, k}^{F}$ and $Y_{i}$ is the nominal GDP of country $i$ in local currency units. We can compare the relative growth of real military capacity in each country by deflating the ratio of nominal spending in two countries, $i$ relative to $k$, in local currency units, using RMC exchange rates $e_{i, k}^{T}$ and $e_{i, k}^{F}$.

It can be seen that the GDP of China measured in units of military output in 2010 is between $90 \%-96 \%$ of the USA using the Törnqvist and Fisher indices. Again this is larger than the relative size suggested by standard PPP comparisons of GDP of approximately $75 \%$ and reflects the low quality adjusted labor costs in China. Likewise however it again reinforces the key result that the relative military size is much closer to the ratios suggested by PPP exchange rate comparisons than market exchange rate comparisons. 
In terms of growth rates, however, panel (iv) of Figure 8 shows that the growth of China's military capacity has been much slower than suggested by standard measures. Specifically the Fisher RMC index suggests that China's real potential military output, given a constant fraction of spending from GDP, has expanded by $92 \%$ relative to the USA - which is much slower than the $235 \%$ increase obtained using market exchange rates and the $140 \%$ increase obtained using PPP exchange rates.

The key insight in terms of growth rates, therefore, is again that China's military costs have been growing faster than suggested by conventional price indices due to rising personnel costs, despite the rising exchange rate. Consequently its real military capacity either based on current spending or potential spending - is growing more slowly than the existing literature suggests. This slower growth is due to the impact of China's rising wages on military costs. As discussed above, this is an instance of the more general phenomenon of "Baumol's costs disease" which applies to sectors that tend to use labor intensively particularly if labor is not substitutable for capital or equipment. ${ }^{22}$

\subsection{Technological Change and Modernization}

In the preceding analysis we have assumed that the rate of technological progress in both China and USA military sectors is constant. Superficially this might appear to be contradicted by what has been widely described as China's "military modernization" as described, for example, by the U.S. Department of Defense (2011), IISS (2012), or Shambaugh (2013).

Explanations for this process of modernization typically focus on the the USA's success in the two Iraq wars, which demonstrated the superiority of new technologies against large forces. Thus according to Thompson (2010) and White (2012), the first Gulf War showed how a large army, in terms of personnel, could be overcome by technological advantage, which led China to respond with a policy of modernization. Shambaugh (2013) also points to China's experiences of large losses in the 1979 Sino-Vietnamese War, the 1995/1996 Taiwan Strait missile crisis where the USA demonstrated its capacity to project its military presence, the USA demonstration of stealth technologies in Serbia in 1999 and use of arial drones in Afghanistan and Iraq since 2001. According to Shambaugh (2013) part of this process of modernization has been cutting the size of ground forces over the decade 1995-2005 and also significantly invested in new naval and air-force capabilities. Thus, for example, the U.S. Department of Defense (2011), p.43, state that

\footnotetext{
${ }^{22}$ Note that by construction the ratios of the various military spending indices are the same as the ratios of the real GDP measures. For example it must be the case that $m_{i, k}^{T} / m_{i, k}^{F}=y_{i, k}^{T} / y_{i, k}^{F}$.
} 
while in 2000 less than $5 \%$ of China's Air and naval forces were considered "modern", by 2010 between $20-40 \%$ were considered "modern" ${ }^{23}$

This "military modernization" is widely interpreted as a sign of a more ambitious or aggressive military stance by China. Nevertheless the preceding analysis suggests that what appears as modernization also may be interpreted as a purely economic response. Specifically the cost minimization decision, described in 1, suggests that the rising wage and salary costs faced by China's defence sector would result in a substitution towards equipment and away from personnel. Thus, notwithstanding the political analysis, the preceding analysis points to an economic motivation for China's so-called military modernization. It can be seen as, at least in part, an economic response to China's growth and rising productivity in manufacturing.

\section{Conclusion}

How big is China? Many analysts have asked this question and economists have provided conventional answers based on different criteria, such as welfare or the ability to affect world supply and demand using exchange rates and different PPP price indices. Sometimes, perhaps most often, the question is asked for political purposes - to assess China's new political standing in international affairs, or for strategic reasons to assess its capacity to project political influence in the region based on credible military capacity. Despite the extensive political and economic discussion of this issue, there is widespread dissatisfaction in the military and strategic literature on existing international comparisons of GDP or military spending for this purpose.

In this paper we have attempted to fill this gap by developing a real military cost (RMC) price index and exchange rate for the purpose of international comparisons of real GDP and military spending. We apply index number theory to develop RMC exchange rate measures that can be readily calculated using publicly available data on wage rates, conventional exchange rate measures and military budget shares.

We then apply these exchange rates to assess the level and growth in China's real military capacity relative to the USA. We find that in military terms, China is very large relative

\footnotetext{
${ }^{23}$ The U.S. Department of Defense (2011) gives the example of the ability of a submarine to launch a cruise missile as an example of "modern". According to Crane et al (2005) China's strategy for improving the technological capabilities of its defence industries has three main elements: modernization of technology; civil-military integration, for example by reforming defence procurement with competitive bidding for contracts; and to exploit advanced foreign technology through imports of weapons, equipment, and military technologies.
} 
to the USA. Specifically it is above the level implied both by market and PPP exchange rates, and much closer in size to the larger PPP based estimates.

Nevertheless we also show that the growth in China's real military capacity over the last decade is much smaller than conventional estimates. For example, using the Fisher index we find that China's real military spending has only grown by $32 \%$ compared to conventional measures of $131 \%$. Likewise growth in potential military capacity measured by nominal GDP deflated by our RMC exchange rates, suggests a growth rate of $92 \%$ over a decade, which is lower than conventional market exchange rate comparisons $(235 \%)$ and also lower than standard PPP comparisons (140\%).

The difference between our measures and the existing conventional measures is that the RMC gives an appropriate weight to the relatively high component of personnel costs in military budgets. Because of rapidly rising wages, a larger fraction of China's expenditure on military or defence spending is taken up with personnel costs. The result is an example of "Baumol's cost disease" afflicting the Chinese military as a consequence of its rapid growth in manufacturing.

The results therefore point to a relatively circumspect re-interpretation of China's rising economic and military strength. The existing literature emphasizes that China's economic growth allows it to expand its military with no additional burden on government budgets. We have shown, however, that this trend is tempered substantially by rising personnel costs due to rising wages in China. Hence, even though China's military capacity is shown to be large, due to its ability to draw on a large supply of labor at relatively low cost, the growth in its capacity over the last decade appears to have been smaller than conventional studies suggest. In particular the benefits of an appreciating exchange rate on the costs of military imports has been more than offset by rising personnel costs. Likewise China's observed "modernization" can be seen as an economic response to substitute toward equipment and away from personnel in the face of these rising wage costs. 


\section{Appendix 1: Deriving The Fisher Index}

The Fisher "Ideal" index is a well known analytical concept but for completeness we briefly discuss the construction of the index using price and share data from military budgets. The Fisher price index is a geometric average of the Laspeyres and Paasche price indices and likewise the Fisher quantity index is the geometric average of the Laspeyres and Paasche price indices.

Thus suppose we think of country $k$ as a base or reference country, we can define the value of $i$ 's purchases of military inputs, evaluated at $k$ 's prices, as a Laspeyres quantity index, $m_{i, k}^{L}$. Likewise $k$ 's outputs valued at $i$ 's prices is then a Paasche quantity index of relative military outputs $m_{i, k}^{P}$.

These are given by

$$
\begin{aligned}
& m_{i, k}^{L}=\frac{\sum p_{k} q_{i}}{\sum p_{k} q_{k}}=\frac{C_{i}}{C_{k}} \frac{1}{e_{i, k}^{P}} \\
& m_{i, k}^{P}=\frac{\sum p_{i} q_{i}}{\sum p_{i} q_{k}}=\frac{C_{i}}{C_{k}} \frac{1}{e_{k, i}^{L}}
\end{aligned}
$$

where $e_{i, k}^{P}$ and $e_{i, k}^{L}$ are the Paasche and Laspeyres price indices given by

$$
\begin{gathered}
e_{i, k}^{P} \equiv\left(\theta_{i} / w_{i, k}+\left(1-\theta_{i}\right) / r_{i, k}\right)^{-1} \\
e_{i, k}^{L} \equiv \theta_{k} w_{i, k}+\left(1-\theta_{k}\right) r_{i, k}
\end{gathered}
$$

Thus the Paasche and Laspeyres price indices, $e_{i, k}^{P}$ and $e_{i, k}^{L}$ are exchange rates that convert units of RMB into US dollars. As noted in the text the Fisher ideal index of the RMC exchange rate is simply

$$
e_{i, k}^{F}=a\left(e_{i, k}^{P} e_{i, k}^{L}\right)^{\frac{1}{2}}
$$

where the technology or efficiency parameter $a$ that allows for differences in technology across countries, assuming that technology change is Solow neutral with resect to all factor and intermediate inputs. ${ }^{24}$ The Fisher quantity index is

$$
m_{i, k}^{F}=\left(C_{i} / C_{k}\right) / e_{i, k}^{F}
$$

\footnotetext{
${ }^{24}$ Diewert (1983) gives a more general result on the impact of technological change on the Fisher price index.
} 


\section{Appendix 2: Labor Compensation Data}

In the results in the main text we uses official Chinese and US manufacturing wage data to represent the relative opportunity costs of military personnel. An alternative is the labor compensation data which is reported by the Bureau of Labor Statistics. Though their data does not include China, the Bureau of Labor Statistics (BLS) have commissioned studies to look at China separately (Banister, and Cook, 2011, Banister 2013). The associated data are available from the BLS's China page, http://www.bls.gov/fls/china.htm. The data from both sources is given in Table A1 along with the RMC exchange rates calculated using the manufacturing compensation data, as opposed to manufacturing wages.

Banister, and Cook (2011) and Banister (2013) report that compensation costs in China were approximately $\$ 1.74$ per worker in 2009 which is $5 \%$ of the USA wage rate. By comparison the manufacturing wage data used in the main text in the same year was $\$$ US3924 per year, or 6.8 percent of the US wage. Thus USA labor costs appear somewhat higher relative to China when various forms of social insurance and employee benefits are included. To that end the use of wage data may overstate the costs of labor in China relative to the USA.

Because of this, by using the BLS compensation data we obtain RMC exchange rates that are smaller than those reports in the main text, reflecting the even lower relative cost of labor in China. Consequently the estimates of China's military capacity are larger. For example in terms of GDP, the BLS data give Fisher Törnqvist quantity indexes of $100 \%$ and $111 \%$ respectively which is slightly larger than the values of 90 and $96 \%$ reported in Figure 8. With respect to growth rates however, the BLS compensation data are very similar, with almost identical growth rates.

Hence using the BLS labor compensation data confirms our find that the RMC exchange rate produces measures of China's military capacity that are larger than the estimates implied of relative GDP or military spending using either market or PPP exchange rates, and does not alter the significantly the conclusions regarding the slower growth of China's military capacity relative to conventional estimates based on PPP or market exchange rates. 


\section{References}

Allen, Robert C., W. Erwin Diewert (1981). "Direct versus Implicit Superlative Index Number Formulae", The Review of Economics and Statistics, 63, 3, pp.430-435.

Baily, Martin Neil, Robert J. Gordon, William D. Nordhaus, David Romer (1988). "The Productivity Slowdown, Measurement Issues, and the Explosion of Computer Power", Brookings Papers on Economic Activity, 1988, 2, pp.347-431.

Ball, N. (1984). "Measuring Third World Security expenditure: A Research Note", World Development, 12, 2, pp.157-164.

Barro Robert, J., and Jong-Wha Lee (2010). "A New Data Set of Educational Attainment in the World, 1950-2010", NBER Working Paper, 15902.

Banister, J., and Cook, G. (2011). Chinas employment and compensation costs in manufacturing through 2008. Monthly Labor Review, 134(3), 39-52.

Banister, Judith (2013) "Chinas manufacturing employment and hourly labor compensation, 2002-2009", Bureau Of Labor Statistics

Beckley, Michael (2012). "China's Century? Why America's Edge Will Endure", International Security, 36, 3, pp.41-78.

Bosworth, Barry and Susan M. Collins (2008). "Accounting for Growth: comparing China and India", Journal of Economic Perspectives, 22, 1, pp.44-66.

Brzoska, Michael (1995). "World military expenditures" in Hartley, Keith and Todd Sandler (eds) Handbook of defense economics, 1, pp.45-67.

Bureau of Labor Statistics. (2012) International Comparison of Hourly Compensation Costs in manufacturing, 2012 www.bls.gov/ilc/ichccaesuppall.xls

Corden, W. M., and J. P.Neary. (1982). "Booming sector and de-industrialisation in a small open economy", The Economic Journal, 92, 368, pp.825-848.

Chan, Steve (2012) Looking for Balance: China, the United States and Power Balancing in East Asia Stanford University Press, Stanford, California

Chen, S. and Ravallion, M. (2010). The developing world is poorer than we thought, but no less successful in the fight against poverty. The Quarterly Journal of Economics $125,4,1577-1625$.

Crane, Keith, Roger Cliff, Evan Medeiros, James Mulvenon and William Overholt (2005). 
"Modernizing China's Military, Opportunities and Constraints", Rand Corporation, Santa Monica, California.

Deaton, Angus and Alan Heston (2010). "Understanding PPPs and PPP-based National Accounts", American Economic Journal: Macroeconomics, 2, 4, pp.1-35.

Diewert, W. E. (1978). "Superlative Index Numbers and Consistency in Aggregation", Econometrica, 46, 4, pp.883-900.

Diewert, W. E. (1983) "The Theory of the Output Price Index and the Measurement of Real Output Change", in Diewert, W.E. and Montmarquette "Price Level Measurement", Statistics Canada, Ottawa.

Diewert, W. Erwin (2010), "Methods of Aggregation above the Basic Heading Level: Linking the Regions," Chapter 8 in Rao D. S. and F. Vogel (eds.), Measuring the Size of the World Economy: A Framework, Methodology and Results from the International Comparison Program (ICP), World Bank, Washington, D.C..

Dobbins, James, David C. Gompert, David A. Shlapak and Andrew Scobell (2011). "Confict with China Prospects, Consequences, and Strategies for Deterrence", Rand Corporation, Santa Monica, California.

Etzioni, A. (2011). "China: Making an adversary", International Politics, 48, 6, pp.647666.

Feenstra, Robert C., Hong Ma, J. Peter Neary, and D.S. Prasada Rao (2013). "Who Shrunk China? Puzzles in the Measurement of Real GDP", The Economic Journal, online: 4 APR 2013, DOI: 10.1111/ecoj.12021.

Fravel, M. T. (2005). Regime Insecurity and International Cooperation: Explaining China's Compromises in Territorial Disputes. International Security 30, 2, 46-83.

Fravel, M. Taylor (2008a). "Power Shifts and Escalation Explaining Chinas Use of Force in Territorial Disputes International Security, 32, 3, pp. 44-83

Fravel, M. Taylor (2008b). "China's search for military power", Washington Quarterly, 31,3 , pp.125-141.

Heston, Alan and Bettina Aten (1993) "Real World Military Expenditures" in Jurgen Brauer and Manas Chatterji (eds) Economic Issues of Disarmament: Contributions from Peace Economics and Peace Science, New York University Press.

Heston, Alan, Robert Summers and Bettina Aten (2012). Penn World Table Version 7.1, 
Center for International Comparisons of Production, Income and Prices at the University of Pennsylvania.

Hill, Robert J. and T. Peter Hill (2009), "Recent Developments in the International Comparison of Prices and Real Output", Macroeconomic Dynamics 13 (supplement no. 2), 194-217.

Hill, R. J. (2006). "Superlative index numbers: not all of them are super", Journal of Econometrics, 130, 1, pp.25-43.

International Institute for Strategic Studies (2006). The Military Balance 2006, International Institute for Strategic Studies, London.

International Institute for Strategic Studies (2012). The Military Balance 2012, International Institute for Strategic Studies, London.

Jorgenson, Dale W. and Kevin J. Stiroh (1999). "Information Technology and Growth", American Economic Review, 89, 2, pp.109-115.

Johnston, A. I. (2013). "How New and Assertive Is China's New Assertiveness?" International Security, 37, 4, 7-48.

Kaplan, R. (2005). "How we would fight China", The Atlantic, 295, 5, pp.49-64.

Kaplan, R.D. (2010). "While U.S. is distracted, China develops sea power", The Washington Post, 26 September.

Klenow, P., and A. Rodriguez-Clare (1997). "The neoclassical revival in growth economics: Has it gone too far?", NBER Macroeconomics Annual, 12, pp.73-103.

Layne, C. (2009). "The waning of US hegemony-myth or reality? A review essay", International Security, 34,1, pp.147-172.

Legro, Jeffrey W. (2007). "What China will want: the future intentions of a rising power" Perspectives on Politics, 5, 3, pp.515-534.

Maddison, A., and H. X. Wu (2008). "Measuring China's Economic Performance", World Economics, 9, 2, pp.13-44.

Mearsheimer, J. J. (2001). The tragedy of great power politics. WW Norton and Company, New York.

Mearsheimer, J. J. (2006). "China's unpeaceful rise", Current History, 105, 690, pp.160162. 
Morgenthau, Hans (1948). Politics Among Nations: The Struggle for Power and Peace, Alfred A. Knopf, New York.

O'Hanlon, Michael (2009). The Science of War, Princeton University Press, N.J.

Peoples' Republic of China (2004). "China's National Defence in 2004", Information Office of the State Council.

Peoples' Republic of China (2008). "China's National Defence in 2008", Information Office of the State Council.

Robertson, Peter E. (2013). "The Global Impact of China's Growth" in Fan, Shenggen, Ravi Kanbur, Shang-Jin Wei and Xiaobo Zhang (eds) The Oxford Companion to the Economics of China (forthcoming).

Shifrinson, Joshua R. Itzkowitz, and Michael Beckley (2012). "Debating China's Rise and US Decline", International Security 37, 3, pp.172-181.

Smith, Ron (2009). Military Economics: The Interaction of Power and Money, Palgrave MacMillan, Hampshire, UK.

Stockholm International Peace Research Institute (SIPRI) (2012). SIPRI Yearbook 2012: Armaments, Disarmament and International Security, Oxford University Press.

Shambaugh, David (2013) China Goes Global: The Partial Power Oxford University Press, N.Y.

Subramanian, Arvind (2011). "The Inevitable Superpower: Why China's Rise Is a Sure Thing", Foreign Affairs, 90, 5, pp.66-78.

Tellis, Ashley J., Janice Bially, Christopher Layne, and Melissa McPherson (2000). Measuring National Power in the Postindustrial Age, RAND Corporation, Santa Monica, California.

The Economist (2010). "The fourth modernisation", Dec 2, 397, 8711, pp.7.

The Economist (2011). "Economics Focus: How To Get A Date", December 31, 401, 8765, pp. 57 .

The Economist (2012a). "Military Strategy: The China Syndrome", June 9, 403, 8788, pp.34.

The Economist (2012b). "China's military rise: The dragon's new teeth. A rare look inside the world's biggest military expansion", April 7, 403, 8779, pp.27. 
Thompson, Drew (2010). "Think Again: China's Military, it's not time to panic. Yet." Foreign Policy, March-April, 178, pp.86.

United Nations (1986). Reduction of Military Budgets: Constriction of military price indices and Purchasing Power Parities for Comparison of Military Expenditures, A/40/421, United Nations, New York.

U.S. Department of Defense (2005). The Military Power of the People's Republic of China, Office of the Secretary of Defense, Annual Report to Congress.

U.S. Department of Defense (2007). The Military Power of the People's Republic of China, Office of the Secretary of Defense, Annual Report to Congress.

U.S. Department of Defense (2011). Military and Security Developments Involving the People's Republic of China, Office of the Secretary of Defense, Annual Report to Congress.

White, H. (2012). "The China Choice: Why America Should Share Power", Black Inc, Collingwood, Victoria, Australia.

Wortzel, Larry M. (2013) The Dragon Extends its Reach: Chinese Military Power goes Global Potomac Books, Washington D.C. 
Figure 1: China and USA Relative GDP Using Market and PPP Exchange Rates

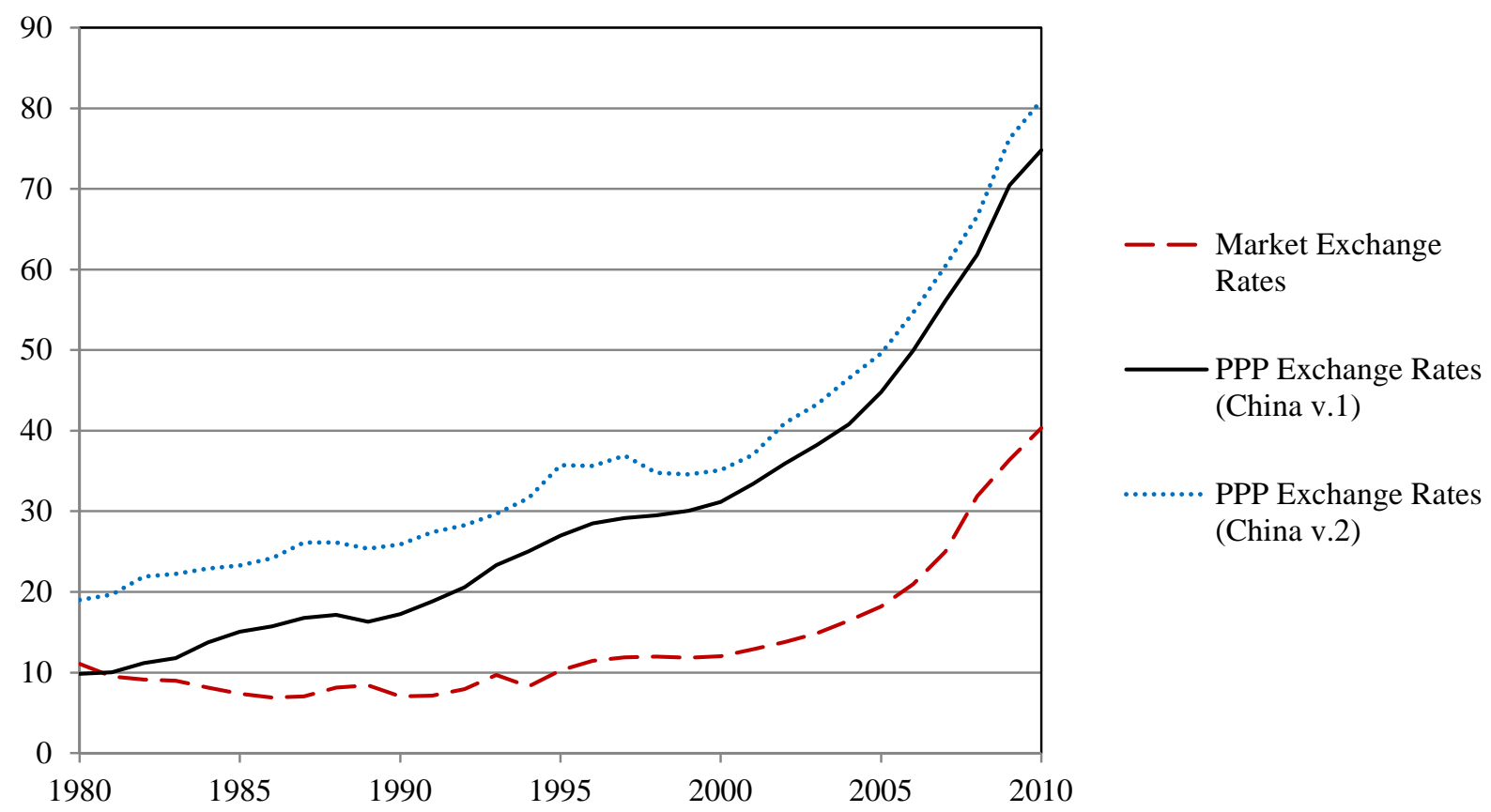

Source Summers, Heston and Atin (2013)

Figure 2: China and USA Shares of Military Spending in GDP

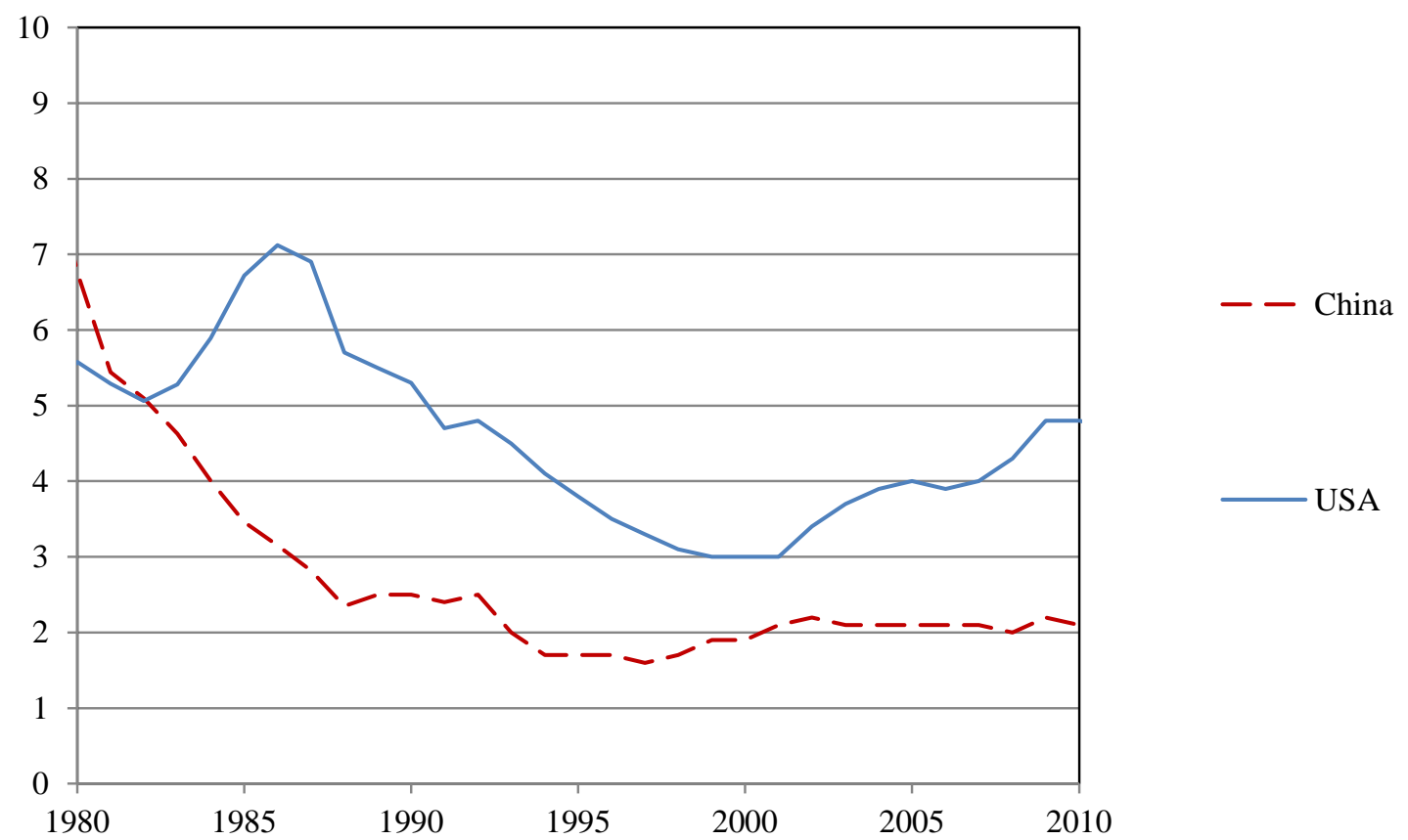

Sources: SIPRI Year Book (2012) , China Statistical Yearbook, http://www.stats.gov.cn/english/statisticaldata/yearlydata, Whitehouse Office of Management and Budget (http://www.whitehouse.gov/omb/budget/Historicals/) and authors calculations. 
Figure 3: China’s Military Spending Relative to the USA (\%)

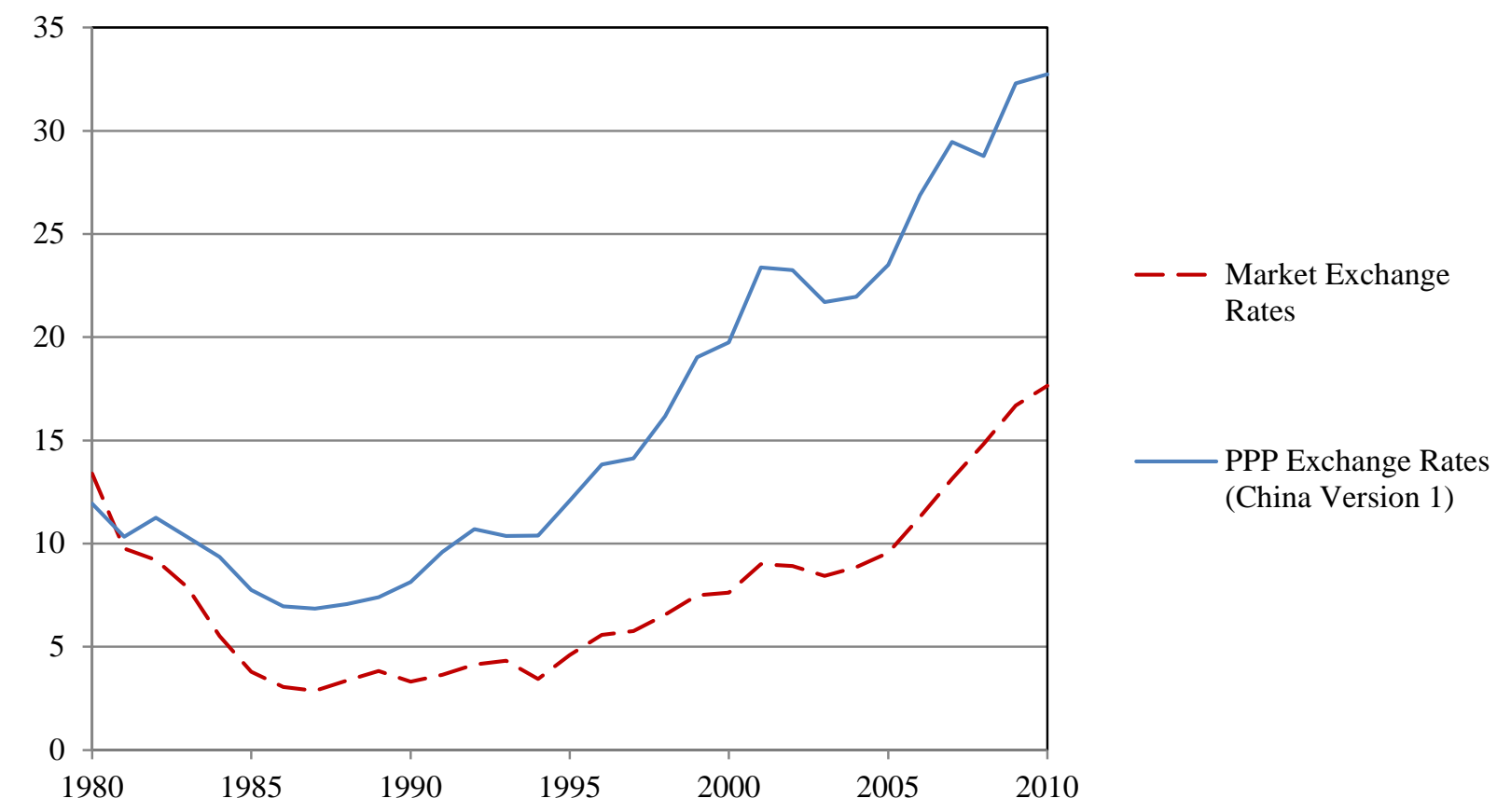

Figure 4: Growth in Chinese Military Spending Relative to USA

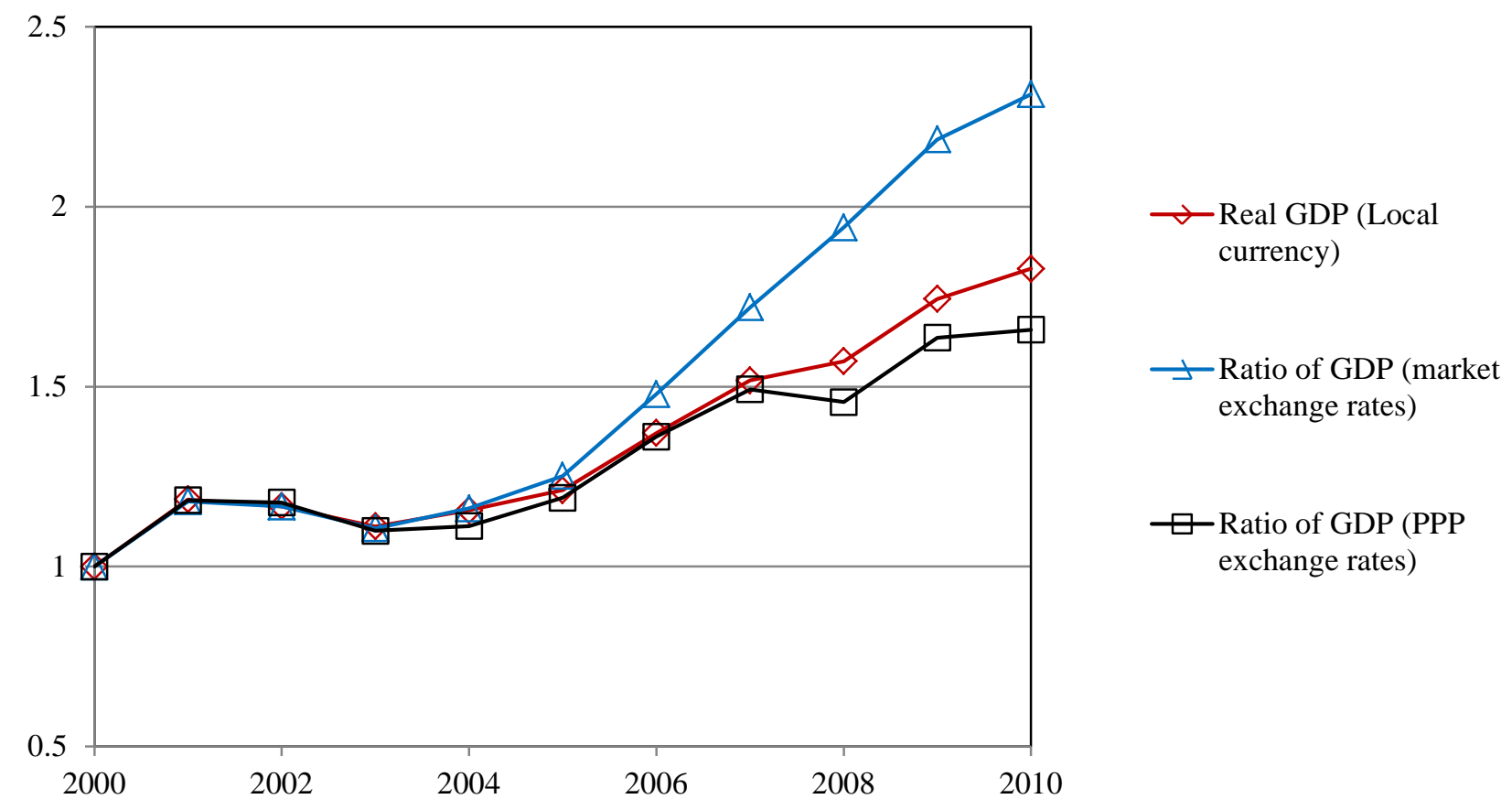


Figure 5: US-China Bilateral Relative Wages and Exchange Rates

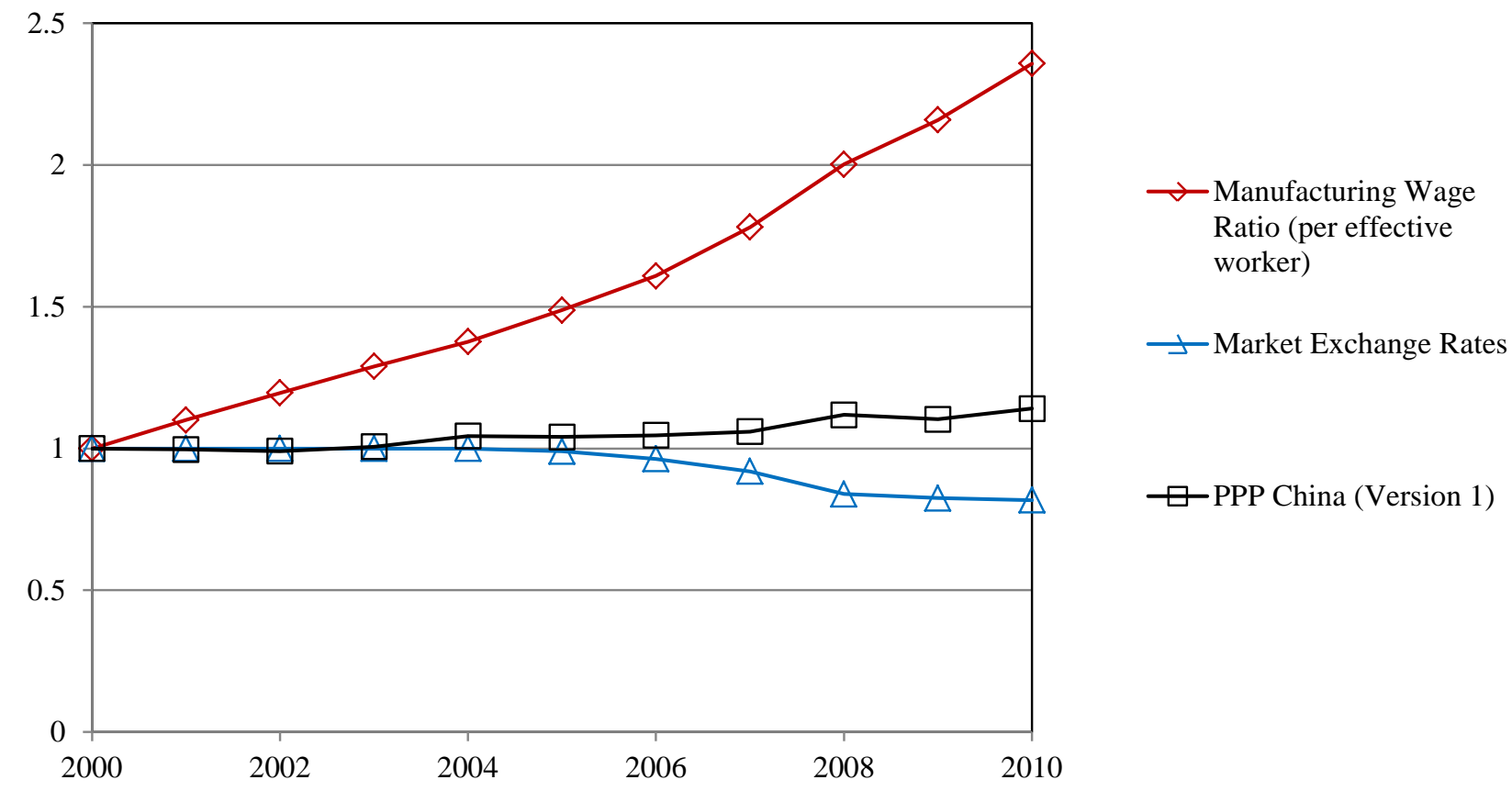

Figure 6: RMC Exchange Rates

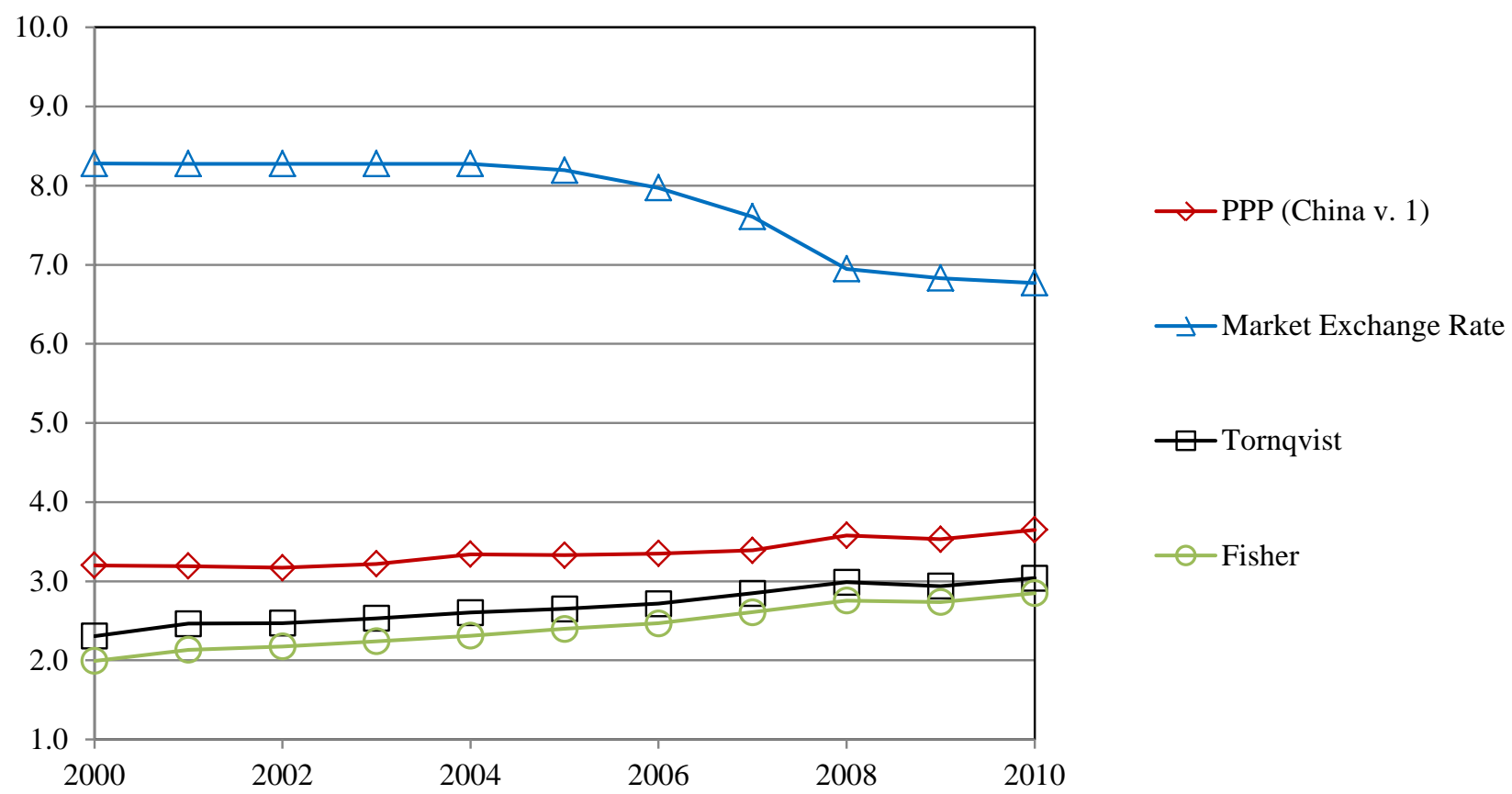


Figure 7: RMC Exchange Rate Index (2000=1)

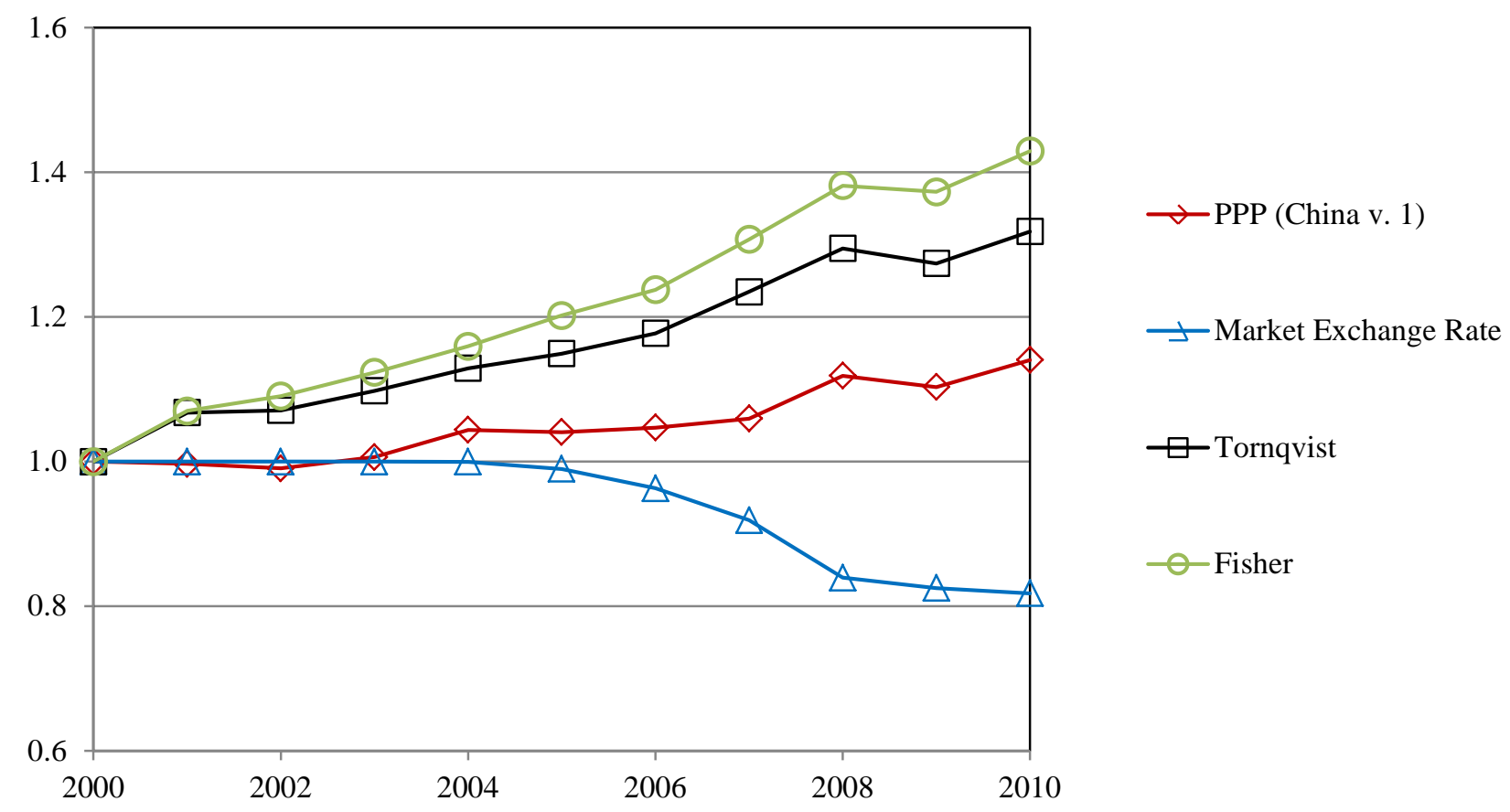


Figure 8: Real Military Capacity - China relative to the USA

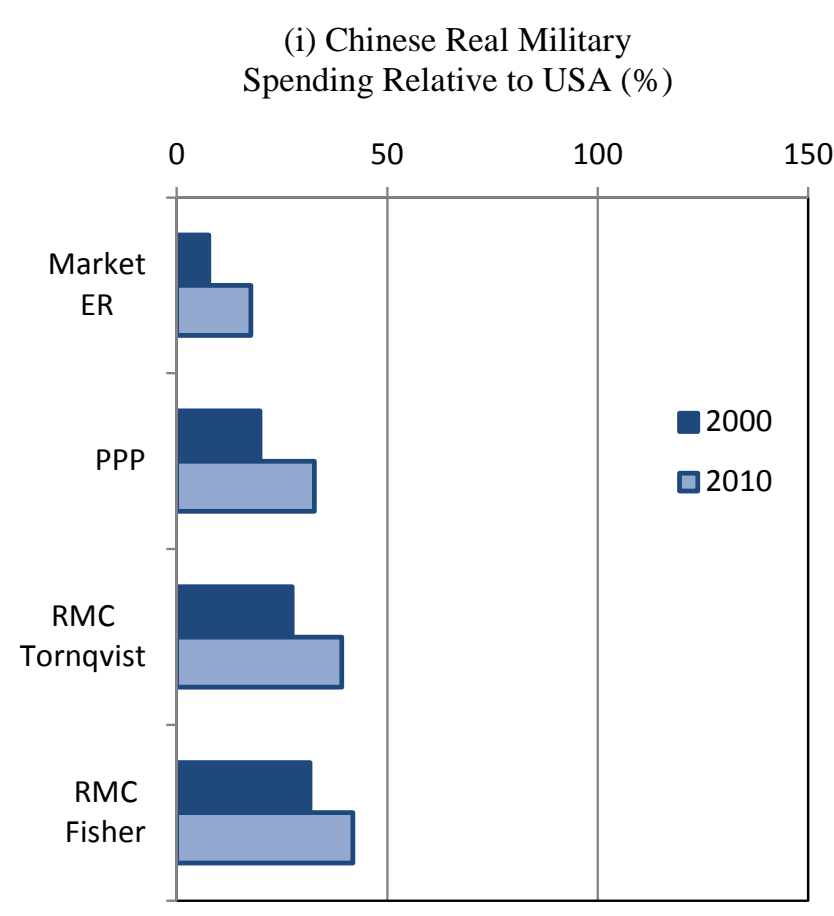

(iii) Chinese GDP

Relative to USA Using RMC Exchange rates (\%)

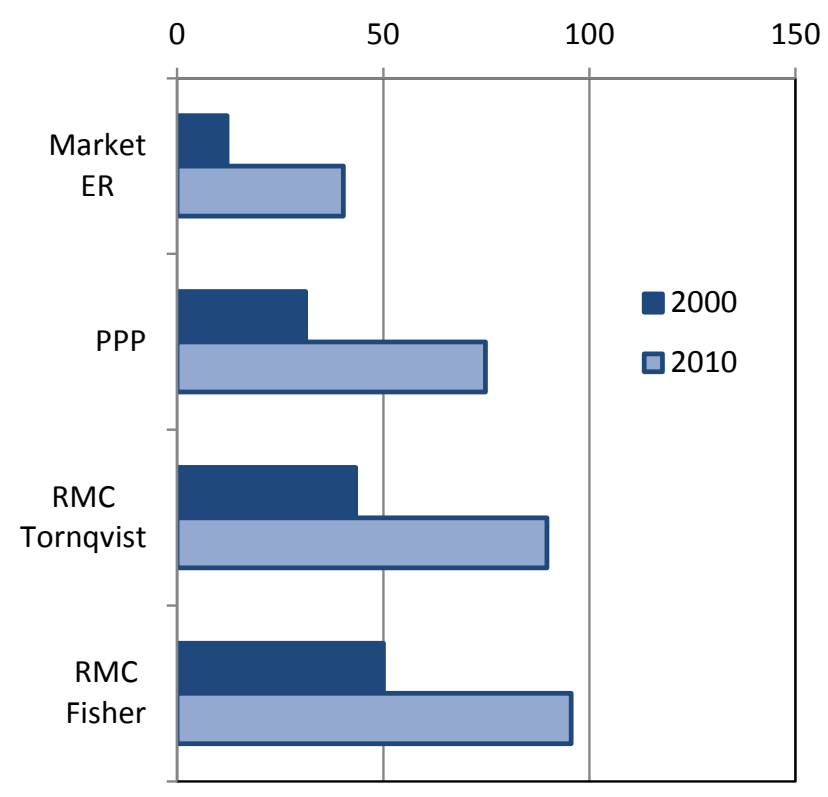

(ii) Growth in Relative

Military Spending 2000-2010 (\%)

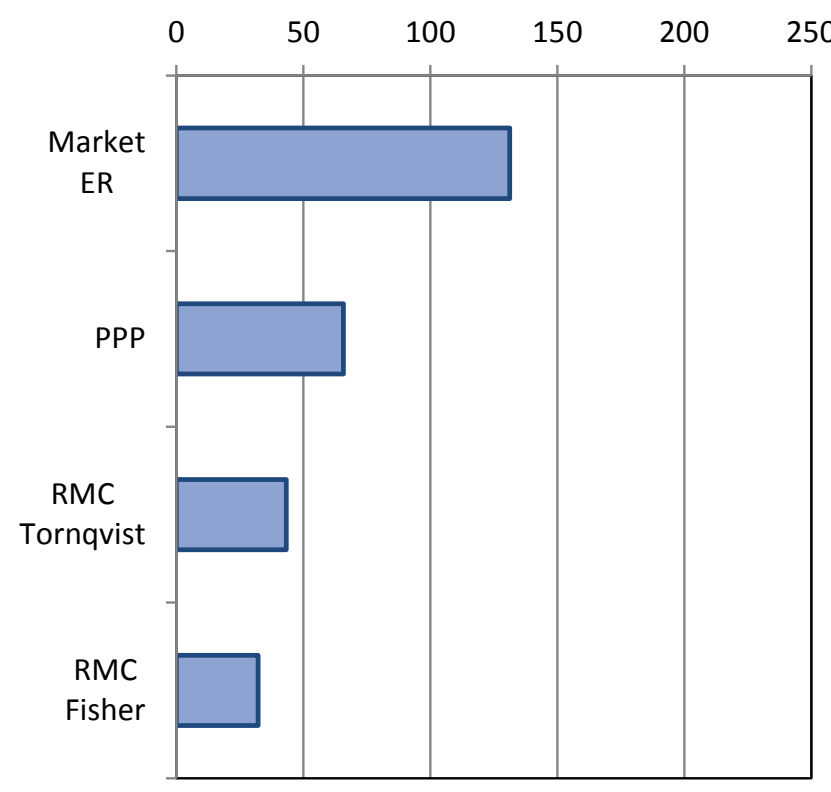

(iv) Growth in Relative

GDP 2000-2010 using RMC Exchange rates (\%)

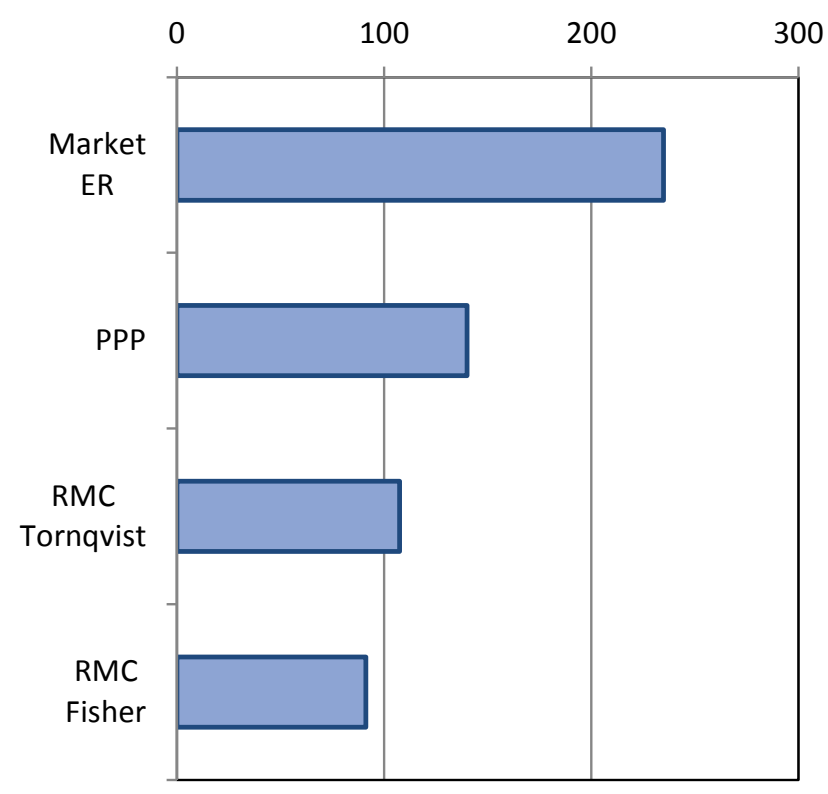


Table 1: Military Budget Shares for China and the USA

\begin{tabular}{|c|c|c|c|c|c|c|}
\hline Year & $\begin{array}{l}\text { USA Personnel } \\
\text { Share }\end{array}$ & $\begin{array}{c}\text { USA Operations } \\
\text { Share }\end{array}$ & $\begin{array}{l}\text { USA Equipment } \\
\text { Share }\end{array}$ & $\begin{array}{c}\text { China Personnel } \\
\text { Share }\end{array}$ & $\begin{array}{c}\text { China Operations } \\
\text { Share }\end{array}$ & $\begin{array}{c}\text { China Equipment } \\
\text { Share }\end{array}$ \\
\hline 2000 & 0.254 & 0.556 & 0.189 & 0.334 & 0.345 & 0.321 \\
\hline 2001 & 0.241 & 0.562 & 0.196 & 0.320 & 0.337 & 0.343 \\
\hline 2002 & 0.252 & 0.566 & 0.182 & 0.319 & 0.343 & 0.338 \\
\hline 2003 & 0.249 & 0.571 & 0.179 & 0.325 & 0.336 & 0.339 \\
\hline 2004 & 0.247 & 0.577 & 0.176 & 0.332 & 0.336 & 0.332 \\
\hline 2005 & 0.251 & 0.550 & 0.200 & 0.338 & 0.336 & 0.326 \\
\hline 2006 & 0.241 & 0.561 & 0.198 & 0.338 & 0.338 & 0.324 \\
\hline 2007 & 0.219 & 0.560 & 0.222 & 0.338 & 0.340 & 0.322 \\
\hline 2008 & 0.206 & 0.549 & 0.245 & 0.339 & 0.339 & 0.322 \\
\hline 2009 & 0.224 & 0.573 & 0.203 & 0.340 & 0.337 & 0.322 \\
\hline 2010 & 0.226 & 0.579 & 0.195 & 0.340 & 0.337 & 0.322 \\
\hline
\end{tabular}

Sources: USA data from http://www.whitehouse.gov/omb/budget/Historicals/ Table 1.2 and excludes the category “Atomic Energy Defense Activities”. For China the data are taken from various issues of the China Defence White papers, China’s National Defence from http://merln.ndu.edu/whitepapers.html 
Table 2: Relative Price Data for China and the USA

\begin{tabular}{|c|c|c|c|c|c|c|}
\hline Year & $\begin{array}{l}\text { Market Exchange Rate } \\
\text { (RMB/Dollar) }\end{array}$ & $\begin{array}{l}\text { PPP Exchange Rate } \\
\text { (RMB/Dollar) }\end{array}$ & $\begin{array}{l}\text { China Manufacturing } \\
\text { Wage and Salaries per } \\
\text { Full-Time Employee }\end{array}$ & $\begin{array}{l}\text { USA Manufacturing } \\
\text { Wage and Salaries per } \\
\text { Full-Time Employee }\end{array}$ & $\begin{array}{l}\text { Effective Workers } \\
\text { (China/USA) }\end{array}$ & $\begin{array}{l}\text { Manu. Wage Ratio per } \\
\text { Effective Worker } \\
\text { (RMB/Dollar) }\end{array}$ \\
\hline 2000 & 8.28 & 3.20 & 8750 & 43933 & 0.43 & 0.46 \\
\hline 2001 & 8.28 & 3.19 & 9774 & 44216 & 0.44 & 0.51 \\
\hline 2002 & 8.28 & 3.17 & 11001 & 45382 & 0.44 & 0.55 \\
\hline 2003 & 8.28 & 3.22 & 12496 & 47393 & 0.44 & 0.60 \\
\hline 2004 & 8.28 & 3.34 & 14033 & 49423 & 0.45 & 0.64 \\
\hline 2005 & 8.19 & 3.33 & 15757 & 50909 & 0.45 & 0.69 \\
\hline 2006 & 7.97 & 3.35 & 17966 & 53152 & 0.46 & 0.74 \\
\hline 2007 & 7.61 & 3.39 & 20884 & 55273 & 0.46 & 0.82 \\
\hline 2008 & 6.95 & 3.58 & 24192 & 56375 & 0.46 & 0.92 \\
\hline 2009 & 6.83 & 3.53 & 26810 & 57383 & 0.47 & 1.00 \\
\hline 2010 & 6.77 & 3.65 & 30916 & 59987 & 0.47 & 1.09 \\
\hline
\end{tabular}

Sources: Chinese Statistical Yearbook http://www.stats.gov.cn/english/statisticaldata/yearlydata/, various years; BEA national Income and Product Accounts 
Table 3: Results

\begin{tabular}{|c|c|c|c|c|c|c|c|c|}
\hline Year & $\begin{array}{l}\text { RMC Törnqvist } \\
\text { (RMB/Dollar) }\end{array}$ & $\begin{array}{l}\text { RMC Fisher } \\
\text { (RMB/Dollar) }\end{array}$ & $\begin{array}{c}\text { Nominal GDP } \\
\text { Ratio } \\
\text { (RMB/Dollar) }\end{array}$ & $\begin{array}{l}\text { RMC GDP Ratio } \\
\text { (Tornqvist) }\end{array}$ & $\begin{array}{l}\text { RMC GDP Ratio } \\
\text { (Fisher) }\end{array}$ & Ratio MX & $\begin{array}{l}\text { RMC MX Ratio } \\
\text { (Törnqvist) }\end{array}$ & $\begin{array}{l}\text { RMC MX Ratio } \\
\text { (Fisher) }\end{array}$ \\
\hline 2000 & 2.31 & 1.99 & 1.00 & 0.43 & 0.50 & 0.63 & 0.27 & 0.32 \\
\hline 2001 & 2.46 & 2.13 & 1.07 & 0.43 & 0.50 & 0.70 & 0.27 & 0.35 \\
\hline 2002 & 2.47 & 2.17 & 1.14 & 0.46 & 0.52 & 0.65 & 0.30 & 0.34 \\
\hline 2003 & 2.53 & 2.24 & 1.23 & 0.49 & 0.55 & 0.57 & 0.30 & 0.31 \\
\hline 2004 & 2.60 & 2.31 & 1.36 & 0.52 & 0.59 & 0.54 & 0.28 & 0.32 \\
\hline 2005 & 2.65 & 2.40 & 1.49 & 0.56 & 0.62 & 0.53 & 0.28 & 0.33 \\
\hline 2006 & 2.72 & 2.47 & 1.67 & 0.62 & 0.68 & 0.54 & 0.30 & 0.36 \\
\hline 2007 & 2.85 & 2.61 & 1.90 & 0.67 & 0.73 & 0.53 & 0.33 & 0.38 \\
\hline 2008 & 2.99 & 2.76 & 2.21 & 0.74 & 0.80 & 0.47 & 0.35 & 0.37 \\
\hline 2009 & 2.94 & 2.74 & 2.49 & 0.85 & 0.91 & 0.46 & 0.34 & 0.42 \\
\hline 2010 & 3.04 & 2.85 & 2.73 & 0.90 & 0.96 & 0.44 & 0.39 & 0.42 \\
\hline
\end{tabular}


Table A1: Urban and Rural Chinese Labour Costs Relative to the USA using BLS Compensation Data

\begin{tabular}{|c|c|c|c|c|c|}
\hline Year & $\begin{array}{c}\text { Average } \\
\text { Chinese Labour } \\
\text { Compensation } \\
\text { (\$US per hour) }\end{array}$ & $\begin{array}{l}\text { US Average } \\
\text { Compensation } \\
\text { Hourly Costs } \\
\text { (\$US per hour) }\end{array}$ & $\begin{array}{l}\text { Average China } \\
\text { Compensation } \\
\text { as a percentage } \\
\text { of USA Labour } \\
\text { Costs }\end{array}$ & $\begin{array}{c}\text { Fisher RMC } \\
\text { Exchange Rate } \\
\text { based of BLS } \\
\text { Data }\end{array}$ & $\begin{array}{c}\text { Fisher RMC } \\
\text { Exchange Rate } \\
\text { based of BLS } \\
\text { Data }\end{array}$ \\
\hline 2002 & 0.60 & 27.36 & 2.19 & 1.92 & 2.27 \\
\hline 2003 & 0.68 & 28.57 & 2.38 & 1.98 & 2.33 \\
\hline 2004 & 0.74 & 29.31 & 2.52 & 2.03 & 2.38 \\
\hline 2005 & 0.83 & 30.14 & 2.75 & 2.10 & 2.42 \\
\hline 2006 & 0.95 & 30.48 & 3.12 & 2.17 & 2.48 \\
\hline 2007 & 1.21 & 32.07 & 3.77 & 2.33 & 2.64 \\
\hline 2008 & 1.59 & 32.78 & 4.85 & 2.50 & 2.80 \\
\hline 2009 & 1.74 & 34.19 & 5.09 & 1.92 & 2.27 \\
\hline
\end{tabular}

Source: Banister and Cook (2011), Banister (2013) and authors’ calculations 
Editor, UWA Economics Discussion Papers:

Ernst Juerg Weber

Business School - Economics

University of Western Australia

35 Sterling Hwy

Crawley WA 6009

Australia

Email: ecoadmin@biz.uwa.edu.au

The Economics Discussion Papers are available at:

1980 - 2002: http://ecompapers.biz.uwa.edu.au/paper/PDF\%20of\%20Discussion\%20Papers/

Since 2001: http://ideas.repec.org/s/uwa/wpaper1.html

Since 2004: $\quad$ http://www.business.uwa.edu.au/school/disciplines/economics

\begin{tabular}{|c|c|c|}
\hline \multicolumn{3}{|c|}{$\begin{array}{l}\text { ECONOMICS DISCUSSION PAPERS } \\
2011\end{array}$} \\
\hline $\begin{array}{l}\text { DP } \\
\text { NUMBER }\end{array}$ & AUTHORS & TITLE \\
\hline 11.01 & Robertson, P.E. & $\begin{array}{l}\text { DEEP IMPACT: CHINA AND THE WORLD } \\
\text { ECONOMY }\end{array}$ \\
\hline 11.02 & Kang, C. and Lee, S.H. & $\begin{array}{l}\text { BEING KNOWLEDGEABLE OR SOCIABLE? } \\
\text { DIFFERENCES IN RELATIVE IMPORTANCE OF } \\
\text { COGNITIVE AND NON-COGNITIVE SKILLS }\end{array}$ \\
\hline 11.03 & Turkington, D. & DIFFERENT CONCEPTS OF MATRIX CALCULUS \\
\hline 11.04 & Golley, J. and Tyers, R. & $\begin{array}{l}\text { CONTRASTING GIANTS: DEMOGRAPHIC CHANGE } \\
\text { AND ECONOMIC PERFORMANCE IN CHINA AND } \\
\text { INDIA }\end{array}$ \\
\hline 11.05 & Collins, J., Baer, B. and Weber, E.J. & $\begin{array}{l}\text { ECONOMIC GROWTH AND EVOLUTION: } \\
\text { PARENTAL PREFERENCE FOR QUALITY AND } \\
\text { QUANTITY OF OFFSPRING }\end{array}$ \\
\hline 11.06 & Turkington, D. & $\begin{array}{l}\text { ON THE DIFFERENTIATION OF THE LOG } \\
\text { LIKELIHOOD FUNCTION USING MATRIX } \\
\text { CALCULUS }\end{array}$ \\
\hline 11.07 & Groenewold, N. and Paterson, J.E.H. & $\begin{array}{l}\text { STOCK PRICES AND EXCHANGE RATES IN } \\
\text { AUSTRALIA: ARE COMMODITY PRICES THE } \\
\text { MISSING LINK? }\end{array}$ \\
\hline 11.08 & Chen, A. and Groenewold, N. & $\begin{array}{l}\text { REDUCING REGIONAL DISPARITIES IN CHINA: IS } \\
\text { INVESTMENT ALLOCATION POLICY EFFECTIVE? }\end{array}$ \\
\hline 11.09 & Williams, A., Birch, E. and Hancock, P. & $\begin{array}{l}\text { THE IMPACT OF ON-LINE LECTURE RECORDINGS } \\
\text { ON STUDENT PERFORMANCE }\end{array}$ \\
\hline 11.10 & Pawley, J. and Weber, E.J. & $\begin{array}{l}\text { INVESTMENT AND TECHNICAL PROGRESS IN THE } \\
\text { G7 COUNTRIES AND AUSTRALIA }\end{array}$ \\
\hline 11.11 & Tyers, R. & $\begin{array}{l}\text { AN ELEMENTAL MACROECONOMIC MODEL FOR } \\
\text { APPLIED ANALYSIS AT UNDERGRADUATE LEVEL }\end{array}$ \\
\hline 11.12 & Clements, K.W. and Gao, G. & QUALITY, QUANTITY, SPENDING AND PRICES \\
\hline 11.13 & Tyers, R. and Zhang, Y. & $\begin{array}{l}\text { JAPAN'S ECONOMIC RECOVERY: INSIGHTS FROM } \\
\text { MULTI-REGION DYNAMICS }\end{array}$ \\
\hline
\end{tabular}




\begin{tabular}{|c|c|c|}
\hline 11.14 & McLure, M. & A. C. PIGOU'S REJECTION OF PARETO'S LAW \\
\hline 11.15 & Kristoffersen, I. & $\begin{array}{l}\text { THE SUBJECTIVE WELLBEING SCALE: HOW } \\
\text { REASONABLE IS THE CARDINALITY } \\
\text { ASSUMPTION? }\end{array}$ \\
\hline 11.16 & Clements, K.W., Izan, H.Y. and Lan, Y. & VOLATILITY AND STOCK PRICE INDEXES \\
\hline 11.17 & Parkinson, $\mathrm{M}$. & $\begin{array}{l}\text { SHANN MEMORIAL LECTURE 2011: SUSTAINABLE } \\
\text { WELLBEING - AN ECONOMIC FUTURE FOR } \\
\text { AUSTRALIA }\end{array}$ \\
\hline 11.18 & Chen, A. and Groenewold, N. & $\begin{array}{l}\text { THE NATIONAL AND REGIONAL EFFECTS OF } \\
\text { FISCAL DECENTRALISATION IN CHINA }\end{array}$ \\
\hline 11.19 & Tyers, R. and Corbett, J. & $\begin{array}{l}\text { JAPAN'S ECONOMIC SLOWDOWN AND ITS } \\
\text { GLOBAL IMPLICATIONS: A REVIEW OF THE } \\
\text { ECONOMIC MODELLING }\end{array}$ \\
\hline 11.20 & $\mathrm{Wu}, \mathrm{Y}$. & $\begin{array}{l}\text { GAS MARKET INTEGRATION: GLOBAL TRENDS } \\
\text { AND IMPLICATIONS FOR THE EAS REGION }\end{array}$ \\
\hline 11.21 & Fu, D., Wu, Y. and Tang, Y. & $\begin{array}{l}\text { DOES INNOVATION MATTER FOR CHINESE HIGH- } \\
\text { TECH EXPORTS? A FIRM-LEVEL ANALYSIS }\end{array}$ \\
\hline 11.22 & $\mathrm{Fu}, \mathrm{D}$. and $\mathrm{Wu}, \mathrm{Y}$. & $\begin{array}{l}\text { EXPORT WAGE PREMIUM IN CHINA’S } \\
\text { MANUFACTURING SECTOR: A FIRM LEVEL } \\
\text { ANALYSIS }\end{array}$ \\
\hline 11.23 & Li, B. and Zhang, J. & $\begin{array}{l}\text { SUBSIDIES IN AN ECONOMY WITH ENDOGENOUS } \\
\text { CYCLES OVER NEOCLASSICAL INVESTMENT AND } \\
\text { NEO-SCHUMPETERIAN INNOVATION REGIMES }\end{array}$ \\
\hline 11.24 & Krey, B., Widmer, P.K. and Zweifel, P. & $\begin{array}{l}\text { EFFICIENT PROVISION OF ELECTRICITY FOR THE } \\
\text { UNITED STATES AND SWITZERLAND }\end{array}$ \\
\hline 11.25 & $\mathrm{Wu}, \mathrm{Y}$. & $\begin{array}{l}\text { ENERGY INTENSITY AND ITS DETERMINANTS IN } \\
\text { CHINA'S REGIONAL ECONOMIES }\end{array}$ \\
\hline
\end{tabular}




\section{ECONOMICS DISCUSSION PAPERS}

2012

\begin{tabular}{|c|c|c|}
\hline $\begin{array}{l}\text { DP } \\
\text { NUMBER }\end{array}$ & AUTHORS & TITLE \\
\hline 12.01 & $\begin{array}{l}\text { Clements, K.W., Gao, G., and } \\
\text { Simpson, T. }\end{array}$ & $\begin{array}{l}\text { DISPARITIES IN INCOMES AND PRICES } \\
\text { INTERNATIONALLY }\end{array}$ \\
\hline 12.02 & Tyers, R. & $\begin{array}{l}\text { THE RISE AND ROBUSTNESS OF ECONOMIC FREEDOM } \\
\text { IN CHINA }\end{array}$ \\
\hline 12.03 & Golley, J. and Tyers, R. & $\begin{array}{l}\text { DEMOGRAPHIC DIVIDENDS, DEPENDENCIES AND } \\
\text { ECONOMIC GROWTH IN CHINA AND INDIA }\end{array}$ \\
\hline 12.04 & Tyers, R. & LOOKING INWARD FOR GROWTH \\
\hline 12.05 & Knight, K. and McLure, M. & THE ELUSIVE ARTHUR PIGOU \\
\hline 12.06 & McLure, M. & $\begin{array}{l}\text { ONE HUNDRED YEARS FROM TODAY: A. C. PIGOU'S } \\
\text { WEALTH AND WELFARE }\end{array}$ \\
\hline 12.07 & Khuu, A. and Weber, E.J. & HOW AUSTRALIAN FARMERS DEAL WITH RISK \\
\hline 12.08 & Chen, M. and Clements, K.W. & PATTERNS IN WORLD METALS PRICES \\
\hline 12.09 & Clements, K.W. & UWA ECONOMICS HONOURS \\
\hline 12.10 & Golley, J. and Tyers, R. & $\begin{array}{l}\text { CHINA'S GENDER IMBALANCE AND ITS ECONOMIC } \\
\text { PERFORMANCE }\end{array}$ \\
\hline 12.11 & Weber, E.J. & $\begin{array}{l}\text { AUSTRALIAN FISCAL POLICY IN THE AFTERMATH OF } \\
\text { THE GLOBAL FINANCIAL CRISIS }\end{array}$ \\
\hline 12.12 & Hartley, P.R. and Medlock III, K.B. & $\begin{array}{l}\text { CHANGES IN THE OPERATIONAL EFFICIENCY OF } \\
\text { NATIONAL OIL COMPANIES }\end{array}$ \\
\hline 12.13 & Li, L. & $\begin{array}{l}\text { HOW MUCH ARE RESOURCE PROJECTS WORTH? A } \\
\text { CAPITAL MARKET PERSPECTIVE }\end{array}$ \\
\hline 12.14 & Chen, A. and Groenewold, N. & $\begin{array}{l}\text { THE REGIONAL ECONOMIC EFFECTS OF A } \\
\text { REDUCTION IN CARBON EMISSIONS AND AN } \\
\text { EVALUATION OF OFFSETTING POLICIES IN CHINA }\end{array}$ \\
\hline 12.15 & Collins, J., Baer, B. and Weber, E.J. & $\begin{array}{l}\text { SEXUAL SELECTION, CONSPICUOUS CONSUMPTION } \\
\text { AND ECONOMIC GROWTH }\end{array}$ \\
\hline 12.16 & Wu, Y. & TRENDS AND PROSPECTS IN CHINA'S R\&D SECTOR \\
\hline 12.17 & Cheong, T.S. and Wu, Y. & $\begin{array}{l}\text { INTRA-PROVINCIAL INEQUALITY IN CHINA: AN } \\
\text { ANALYSIS OF COUNTY-LEVEL DATA }\end{array}$ \\
\hline 12.18 & Cheong, T.S. & THE PATTERNS OF REGIONAL INEQUALITY IN CHINA \\
\hline 12.19 & Wu, Y. & $\begin{array}{l}\text { ELECTRICITY MARKET INTEGRATION: GLOBAL } \\
\text { TRENDS AND IMPLICATIONS FOR THE EAS REGION }\end{array}$ \\
\hline 12.20 & Knight, K. & $\begin{array}{l}\text { EXEGESIS OF DIGITAL TEXT FROM THE HISTORY OF } \\
\text { ECONOMIC THOUGHT: A COMPARATIVE } \\
\text { EXPLORATORY TEST }\end{array}$ \\
\hline 12.21 & Chatterjee, I. & $\begin{array}{l}\text { COSTLY REPORTING, EX-POST MONITORING, AND } \\
\text { COMMERCIAL PIRACY: A GAME THEORETIC } \\
\text { ANALYSIS }\end{array}$ \\
\hline 12.22 & Pen, S.E. & QUALITY-CONSTANT ILLICIT DRUG PRICES \\
\hline 12.23 & Cheong, T.S. and Wu, Y. & $\begin{array}{l}\text { REGIONAL DISPARITY, TRANSITIONAL DYNAMICS } \\
\text { AND CONVERGENCE IN CHINA }\end{array}$ \\
\hline
\end{tabular}




\begin{tabular}{|l|l|l|}
\hline 12.24 & Ezzati, P. & $\begin{array}{l}\text { FINANCIAL MARKETS INTEGRATION OF IRAN } \\
\text { WITHIN THE MIDDLE EAST AND WITH THE REST OF } \\
\text { THE WORLD }\end{array}$ \\
\hline 12.25 & Kwan, F., Wu, Y. and Zhuo, S. & $\begin{array}{l}\text { RE-EXAMINATION OF THE SURPLUS AGRICULTURAL } \\
\text { LABOUR IN CHINA }\end{array}$ \\
\hline 12.26 & Wu, Y. & R\&D BEHAVIOUR IN CHINESE FIRMS \\
\hline 12.27 & Tang, S.H.K. and Yung, L.C.W. & $\begin{array}{l}\text { MAIDS OR MENTORS? THE EFFECTS OF LIVE-IN } \\
\text { FOREIGN DOMESTIC WORKERS ON SCHOOL } \\
\text { CHILDREN'S EDUCATIONAL ACHIEVEMENT IN HONG } \\
\text { KONG }\end{array}$ \\
\hline 12.28 & Groenewold, $\mathrm{N}$. & $\begin{array}{l}\text { AUSTRALIA AND THE GFC: SAVED BY ASTUTE } \\
\text { FISCAL POLICY? }\end{array}$ \\
\hline
\end{tabular}

\section{ECONOMICS DISCUSSION PAPERS \\ 2013}

\begin{tabular}{|c|c|c|}
\hline $\begin{array}{l}\text { DP } \\
\text { NUMBER }\end{array}$ & AUTHORS & TITLE \\
\hline 13.01 & $\begin{array}{l}\text { Chen, M., Clements, K.W. and } \\
\text { Gao, G. }\end{array}$ & THREE FACTS ABOUT WORLD METAL PRICES \\
\hline 13.02 & Collins, J. and Richards, O. & $\begin{array}{l}\text { EVOLUTION, FERTILITY AND THE AGEING } \\
\text { POPULATION }\end{array}$ \\
\hline 13.03 & $\begin{array}{l}\text { Clements, K., Genberg, H., } \\
\text { Harberger, A., Lothian, J., } \\
\text { Mundell, R., Sonnenschein, H. and } \\
\text { Tolley, G. }\end{array}$ & LARRY SJAASTAD, 1934-2012 \\
\hline 13.04 & Robitaille, M.C. and Chatterjee, I. & MOTHERS-IN-LAW AND SON PREFERENCE IN INDIA \\
\hline 13.05 & Clements, K.W. and Izan, I.H.Y. & $\begin{array}{l}\text { REPORT ON THE } 25^{\mathrm{TH}} \text { PHD CONFERENCE IN } \\
\text { ECONOMICS AND BUSINESS }\end{array}$ \\
\hline 13.06 & Walker, A. and Tyers, R. & QUANTIFYING AUSTRALIA’S “THREE SPEED” BOOM \\
\hline 13.07 & $\mathrm{Yu}, \mathrm{F}$. and $\mathrm{Wu}, \mathrm{Y}$. & PATENT EXAMINATION AND DISGUISED PROTECTION \\
\hline 13.08 & $\mathrm{Yu}, \mathrm{F}$. and $\mathrm{Wu}, \mathrm{Y}$. & $\begin{array}{l}\text { PATENT CITATIONS AND KNOWLEDGE SPILLOVERS: } \\
\text { AN ANALYSIS OF CHINESE PATENTS REGISTER IN } \\
\text { THE US }\end{array}$ \\
\hline 13.09 & Chatterjee, I. and Saha, B. & BARGAINING DELEGATION IN MONOPOLY \\
\hline 13.10 & Cheong, T.S. and Wu, Y. & $\begin{array}{l}\text { GLOBALIZATION AND REGIONAL INEQUALITY IN } \\
\text { CHINA }\end{array}$ \\
\hline 13.11 & Cheong, T.S. and Wu, Y. & INEQUALITY AND CRIME RATES IN CHINA \\
\hline 13.12 & Robertson, P.E. and Ye, L. & ON THE EXISTENCE OF A MIDDLE INCOME TRAP \\
\hline 13.13 & Robertson, P.E. & THE GLOBAL IMPACT OF CHINA’S GROWTH \\
\hline 13.14 & $\begin{array}{l}\text { Hanaki, N., Jacquemet, N., } \\
\text { Luchini, S., and Zylbersztejn, A. }\end{array}$ & $\begin{array}{l}\text { BOUNDED RATIONALITY AND STRATEGIC } \\
\text { UNCERTAINTY IN A SIMPLE DOMINANCE SOLVABLE } \\
\text { GAME }\end{array}$ \\
\hline 13.15 & $\begin{array}{l}\text { Okatch, Z., Siddique, A. and } \\
\text { Rammohan, A. }\end{array}$ & $\begin{array}{l}\text { DETERMINANTS OF INCOME INEQUALITY IN } \\
\text { BOTSWANA }\end{array}$ \\
\hline 13.16 & Clements, K.W. and Gao, G. & $\begin{array}{l}\text { A MULTI-MARKET APPROACH TO MEASURING THE } \\
\text { CYCLE }\end{array}$ \\
\hline
\end{tabular}




\begin{tabular}{|c|c|c|}
\hline 13.17 & Chatterjee, I. and Ray, R. & $\begin{array}{l}\text { THE ROLE OF INSTITUTIONS IN THE INCIDENCE OF } \\
\text { CRIME AND CORRUPTION }\end{array}$ \\
\hline 13.18 & Fu, D. and $\mathrm{Wu}, \mathrm{Y}$. & $\begin{array}{l}\text { EXPORT SURVIVAL PATTERN AND DETERMINANTS } \\
\text { OF CHINESE MANUFACTURING FIRMS }\end{array}$ \\
\hline 13.19 & Shi, X., Wu, Y. and Zhao, D. & $\begin{array}{l}\text { KNOWLEDGE INTENSIVE BUSINESS SERVICES AND } \\
\text { THEIR IMPACT ON INNOVATION IN CHINA }\end{array}$ \\
\hline 13.20 & $\begin{array}{l}\text { Tyers, R., Zhang, Y. and } \\
\text { Cheong, T.S. }\end{array}$ & $\begin{array}{l}\text { CHINA'S SAVING AND GLOBAL ECONOMIC } \\
\text { PERFORMANCE }\end{array}$ \\
\hline 13.21 & Collins, J., Baer, B. and Weber, E.J. & $\begin{array}{l}\text { POPULATION, TECHNOLOGICAL PROGRESS AND THE } \\
\text { EVOLUTION OF INNOVATIVE POTENTIAL }\end{array}$ \\
\hline 13.22 & Hartley, P.R. & THE FUTURE OF LONG-TERM LNG CONTRACTS \\
\hline 13.23 & Tyers, R. & $\begin{array}{l}\text { A SIMPLE MODEL TO STUDY GLOBAL } \\
\text { MACROECONOMIC INTERDEPENDENCE }\end{array}$ \\
\hline 13.24 & McLure, M. & $\begin{array}{l}\text { REFLECTIONS ON THE QUANTITY THEORY: PIGOU IN } \\
1917 \text { AND PARETO IN 1920-21 }\end{array}$ \\
\hline 13.25 & Chen, A. and Groenewold, N. & $\begin{array}{l}\text { REGIONAL EFFECTS OF AN EMISSION-REDUCTION } \\
\text { POLICY IN CHINA: TAXES, SUBSIDIES AND THE } \\
\text { METHOD OF FINANCING }\end{array}$ \\
\hline 13.26 & Siddique, M.A.B. & $\begin{array}{l}\text { TRADE RELATIONS BETWEEN AUSTRALIA AND } \\
\text { THAILAND: } 1990 \text { TO } 2011\end{array}$ \\
\hline 13.27 & Li, B. and Zhang, J. & $\begin{array}{l}\text { GOVERNMENT DEBT IN AN INTERGENERATIONAL } \\
\text { MODEL OF ECONOMIC GROWTH, ENDOGENOUS } \\
\text { FERTILITY, AND ELASTIC LABOR WITH AN } \\
\text { APPLICATION TO JAPAN }\end{array}$ \\
\hline 13.28 & Robitaille, M. and Chatterjee, I. & $\begin{array}{l}\text { SEX-SELECTIVE ABORTIONS AND INFANT } \\
\text { MORTALITY IN INDIA: THE ROLE OF PARENTS' } \\
\text { STATED SON PREFERENCE }\end{array}$ \\
\hline 13.29 & Ezzati, P. & $\begin{array}{l}\text { ANALYSIS OF VOLATILITY SPILLOVER EFFECTS: } \\
\text { TWO-STAGE PROCEDURE BASED ON A MODIFIED } \\
\text { GARCH-M }\end{array}$ \\
\hline 13.30 & Robertson, P. E. & $\begin{array}{l}\text { DOES A FREE MARKET ECONOMY MAKE AUSTRALIA } \\
\text { MORE OR LESS SECURE IN A GLOBALISED WORLD? }\end{array}$ \\
\hline 13.31 & $\begin{array}{l}\text { Das, S., Ghate, C. and } \\
\text { Robertson, P. E. }\end{array}$ & $\begin{array}{l}\text { REMOTENESS AND UNBALANCED GROWTH: } \\
\text { UNDERSTANDING DIVERGENCE ACROSS INDIAN } \\
\text { DISTRICTS }\end{array}$ \\
\hline 13.32 & Robertson, P.E. and Sin, A. & $\begin{array}{l}\text { MEASURING HARD POWER: CHINA'S ECONOMIC } \\
\text { GROWTH AND MILITARY CAPACITY }\end{array}$ \\
\hline
\end{tabular}

